\title{
Fundamental chemistry of iodine. The reaction of di-iodine towards thiourea and its methyl- derivative: formation of aminothiazoles and aminothiadiazoles through dicationic disulfides $\uparrow$
}

Cite this: Dalton Trans., 2014, 43, 4790

\author{
M. Biesiada, ${ }^{a, b}$ N. Kourkoumelis, ${ }^{c}$ M. Kubicki, ${ }^{\star b}$ A. M. Owczarzak, ${ }^{b}$ V. Balas ${ }^{a}$ and \\ S. K. Hadjikakou*a
}

The reactivity of di-iodine towards thiourea (TU) and its derivative methylthiourea (MeTU) was studied. A diversity of products was obtained from these reactions. TU reacted with di-iodine in the absence or presence of hydroiodic or hydrochloric acids in a $1: 1,1: 1: 1$ or $1: 1: 2\left(T U: I_{2}: H X(X=1, C l)\right)$ molar ratio to form the ionic compounds $\left[\left(\mathrm{TU}_{2}\right)^{2+} 2\left(\mathrm{I}^{-}\right) \cdot \mathrm{H}_{2} \mathrm{O}\right](\mathbf{1}),\left[2\left(\mathrm{TU}_{2}\right)^{2+} \cdot\left(\mathrm{Cl}^{-}\right) \cdot 2\left(\mathrm{I}^{-}\right) \cdot\left(\mathrm{I}_{3}^{-}\right)\right](2)$ and $\left[(\mathrm{TUH})^{+}\left(\mathrm{I}_{3}{ }^{-}\right)\right](3)$. The compounds $\left[\left(\mathrm{TU}_{2}\right)^{2+}\left(\mathrm{Br}^{-}\right)\left(\mathrm{I}_{3}^{-}\right)\right](4)$ and $\left[\left(\mathrm{TU}_{2}\right)^{2+} 2\left(\mathrm{Br}^{-}\right) \cdot \mathrm{H}_{2} \mathrm{O}\right](5)$ were derived from the reactions of TU with di-iodine in the presence of hydrobromic acid in a $1: 1: 1$ or $1: 2: 1\left(\mathrm{TU}: \mathrm{I}_{2}: \mathrm{HBr}\right.$ ) molar ratio. However, when the product of the reaction between TU and di-iodine in a $2: 1\left(\mathrm{TU}: \mathrm{I}_{2}\right)$ molar ratio was crystallized in acetone-ethylether media the ionic salt of formula [(DAThdH $\left.\left.{ }^{+}\right)\left(I^{-}\right)\right](6)($ DAThd $=3,5$-diamino-1,2,4thiadiazole) was obtained. Methylthiourea (MeTU) reacted with di-iodine in the presence of hydrobromic acid $\left(1: 1: 1, \mathrm{MeTU}: \mathrm{I}_{2}: \mathrm{HBr}\right)$ in dichloromethane to form a solid product which gives $\left[2\left(\mathrm{MeTU}_{2}\right)^{2+} \cdot\left(2 \mathrm{Br}^{-}\right)\right.$ $\left.\left(\mathrm{I}_{4}{ }^{2-}\right)\right]$ (7). Moreover, MeTU reacted with $\mathrm{I}_{2}$ in $2: 1$ (MeTU: $\mathrm{I}_{2}$ ) to form an intermediate powder product which was crystallized in acetone to give the 2-amino-3,4-dimethylthiazolium cation in [( $\left.\mathrm{DMeAThH}^{+}\right)\left(\mathrm{I}^{-}\right)$$\left(\mathrm{H}_{2} \mathrm{O}\right)$ ] (8). Upon changing the crystallization medium to ethanol, instead of acetone, the cationic 5-amino3-methylamino-4-methyl-1,2,4-thiadiazolium (AMeAThdH) $)^{+}$in $\left[\left(\mathrm{AMeAThdH}^{+}\right)\left(\mathrm{I}_{3}{ }^{-}\right)\right](\mathbf{9})$ was formed. The compounds were characterized by m.p., FT-IR, UV-Vis, ${ }^{1} \mathrm{H}-\mathrm{NMR}$ spectroscopy and mass spectrometry. The crystal structures of compounds $1-\mathbf{9}$ were determined by $\mathrm{X}$-ray crystallography.
Received 22nd November 2013, Accepted 2nd January 2014

DOI: $10.1039 / c 3 d t 53302 f$

www.rsc.org/dalton were also obtained. ${ }^{1-9}$ T-shape adducts, in which two iodine atoms are connected with sulfur creating linear motif I-S-I, are also reported. ${ }^{3}$ The common ligands of these compounds contain the thiocarbamide group. ${ }^{1-9}$ One of the simplest thiocarbamides is thiourea (TU), and its derivative $N$-methylthiourea (MeTU).

Thioamides, like carbimazole (CBZ, 3-methyl-2-thioxo-4imidazoline-1-carboxylate) and methimazole (MMI, $N$-methylimidazoline-2-thione), are used as clinical drugs for the treatment of hyperthyroidism disease. ${ }^{2}$ Moreover, iodine compounds can be applied in semiconductors or superconductors depending on the number of iodine atoms in these materials. $^{7-10}$ Also these compounds were used as oxidation agents, oxidizing the metals, even noble ones, ${ }^{4 h}$ and they were investigated for their magnetic properties. ${ }^{10}$ Both these applications result from the ability of the elements of Group 16 of the periodic table, like sulfur, to form charge transfer complexes. ${ }^{11}$

In 1947, King et al. ${ }^{12}$ demonstrated that ketones react with thiourea and halogens or certain oxidizing agents to give substituted 2-aminothiazoles (Reaction Scheme 1). 


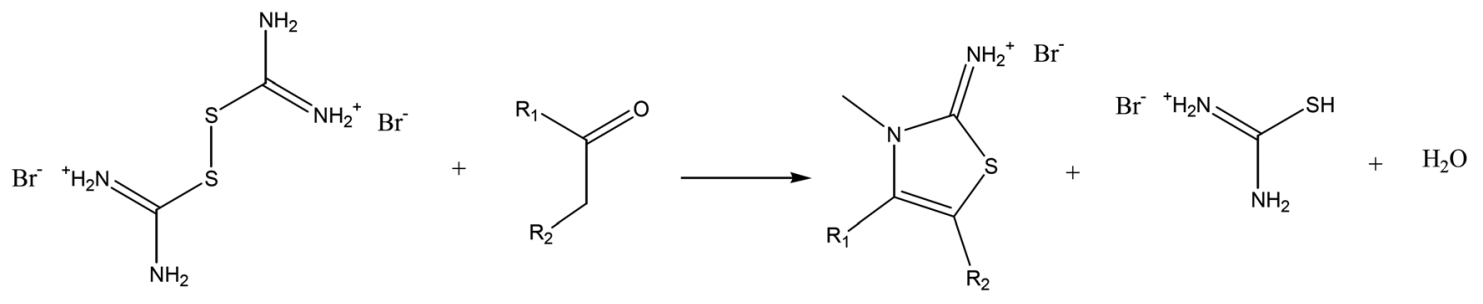

Scheme 1

Due to the importance of aminothiazoles and their derivatives in synthetic organic chemistry Metwally et al. have reviewed the preparation routes for them. ${ }^{13}$ Substituted 2-aminothiazoles and their derivatives have been used as biologically active molecules, ${ }^{14 a}$ as antibacterial, antifungal, ${ }^{14 b-e}$ and anthelmintic agents, ${ }^{14 f}$ as inhibitors ${ }^{14 g}$ and as activators of many biological processes. ${ }^{14 h}$ 2-Aminothiazole derivatives are used in treatment of head twitches, ${ }^{15 a}$ tumors, ${ }^{15 b, c}$ malaria, ${ }^{15 d}$ ulcers, ${ }^{15 e}$ anoxia, ${ }^{15 f}$ and tuberculosis, ${ }^{15 g}$ anxieties, ${ }^{15 h}$ and as chelating agents. ${ }^{16 a-c}$ They are also used in syntheses of dyes $^{17 a}$ and as chemosensors. ${ }^{17 b, c}$ They have also found applications in jet fuels as anticorrosive additives ${ }^{17 d}$ and in radiochemistry as protective compounds. ${ }^{17 e}$

1,2,4-Thiadiazole (Thd) and its derivatives, on the other hand, exhibit many applications and therefore the synthesis of these compounds has been developed for many years. ${ }^{18 a}$ Thd and its derivatives are essentially biologically active compounds. They reveal actions in antihypertensive ${ }^{19 a}$ and cardioprotective treatment. ${ }^{19 b, c}$ They have potential activity as G-protein coupled receptors. ${ }^{19 d}$ Thd inactivates enzymes with active cysteine residues ${ }^{19 e}$ (e.g. bacterial enzymes ${ }^{19 f}$ ) and they are constituents of non-steroidal anti-inflammatory agents. ${ }^{19 g}$ The everyday antibiotic drug cefozopram ${ }^{19 h}$ is also a Thd derivative. Moreover there are indications that it possesses an effective influence on Alzheimer's disease. ${ }^{19 i}$

One of the synthetic routes developed for 1,2,4-thiadiazole derivatives involves the reaction of arylothioamides with chloride or bromide anions and acid in DMSO solution ${ }^{18 b}$ (Reaction Scheme 2).

In this paper we report the synthesis, and the structural and spectroscopic characterization of compounds 1-5 and 7 resulting from the reaction between thiourea (TU) or methylthiourea (MeTU) with di-iodine in the presence or absence of hydrochloric, hydrobromic or hydroiodic acids towards dicationic disulfides with mono- or poly-iodides as counter anions. The ionic salts 6 and 8-9 which contain substituted aminothiazole or thiadiazole rings were obtained by modifying the stoichiometry of the reaction between thiourea

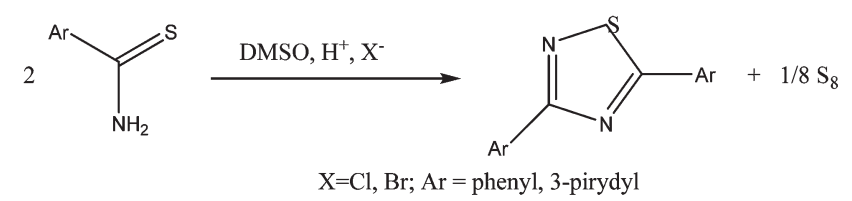

Scheme 2 or methylthiourea (MeTU) and di-iodine followed by crystallization in acetone or ethanol.

\section{Results and discussion}

\section{Reactions}

It is well known that interesting products with a variety of nuclearities could be isolated when chalcogen donors (D) were reacted with halogen independently of the molar ratios of the reactants. ${ }^{1-9}$ For example the poly-iodide chain $\left[\mathrm{I}_{17}\right]^{-}$is formed in $\left\{\left\{(\mathrm{PYOH})_{6}\left[(\mathrm{PYOH})_{2}\right]^{2+}\right\} \quad 0.5 \mathrm{I}^{-} \quad 1.5 \mathrm{I}_{7}^{-} \mathrm{I}_{2}\right\}$ when 2-pyridone reacts with di-iodine in a $1: 2$ molar ratio. ${ }^{2 e}$ Conductivity titration experiments confirm that even poly-iodides of very high nuclearities were obtained at a $1: 2\left(\mathrm{D}: \mathrm{I}_{2}\right)$ molar ratio of the reactants. $^{2 c-e}$ To ascertain the number of the ionic species derived by the di-iodine and TU or MeTU interaction, conductivity titrations in acetonitrile solution were carried out (Fig. 1). At zero $I_{2}$ concentration, the solutions of either TU or MeTU exhibit almost zero conductivity. The conductivity of the solutions increases to a rate value when the $\left[\mathrm{I}_{2}\right]$ : [ligand] molar ratio is $2: 1$ where a stable species is formed in the solution. Further addition of di-iodine increases the conductivity of the solution to higher values, indicating that many types of ionic species could also be obtained in higher ratios.

Since the presence of hydrohalogens in the reaction mixtures might lead to different products (see Reaction Schemes 1 and 2), we extended our studies to the redox reactions of thiourea (TU) or methylthiourea (MeTU) with di-iodine in $2: 1$, $1: 2$ and $1: 1$ (TU: $\mathrm{I}_{2}$ ) molar ratios in the presence or absence

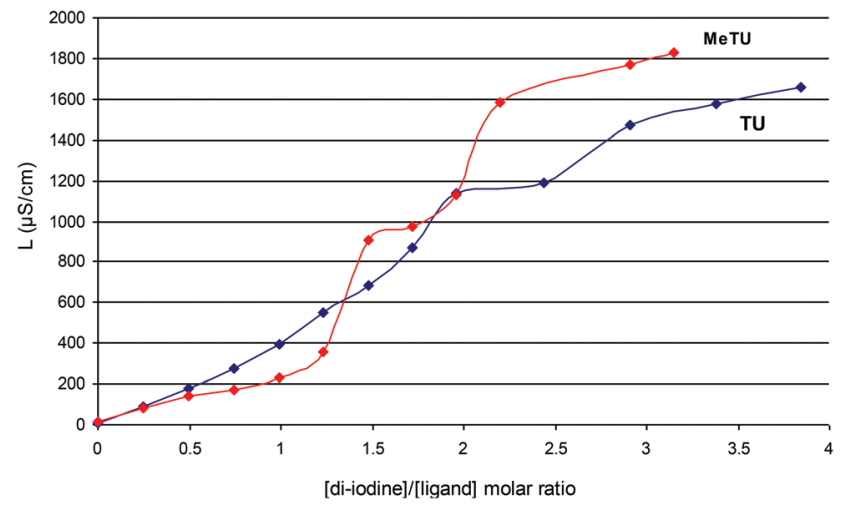

Fig. 1 Conductivity titration of TU or MeTU $\left(10^{-2} \mathrm{M}\right)$ with $\mathrm{I}_{2}$ in acetonitrile $(T=293 \mathrm{~K})$. 
of $\mathrm{HX}(\mathrm{X}=\mathrm{Cl}, \mathrm{Br}, \mathrm{I})$. All products derived from the reactions were characterized by X-ray analysis. Crystals grown from the reaction solutions were refined, even those of the same products. Crystals of $\left[\left(\mathrm{TU}_{2}\right)^{2+} 2\left(\mathrm{I}^{-}\right) \cdot \mathrm{H}_{2} \mathrm{O}\right](\mathbf{1})$, were grown from the crystallization of the product derived from the reaction of $\mathrm{TU}$ with di-iodine (Reaction Scheme 3a). It was also directly formed in the presence of hydroiodic or hydrochloric acids in a $1: 1: 1\left(\mathrm{TU}: \mathrm{I}_{2}: \mathrm{HX} \mathrm{X}=\mathrm{I}, \mathrm{Cl}\right.$ ) ratio (Reaction Scheme $3 \mathrm{~b}$ and $3 \mathrm{c} 1$ ), since hydrohalogens enhance the oxidizing potential of the solution leading to the cationic disulfide formation. Crystals of $\left[2\left(\mathrm{TU}_{2}\right)^{2+} \cdot\left(\mathrm{Cl}^{-}\right) \cdot 2\left(\mathrm{I}^{-}\right) \cdot\left(\mathrm{I}_{3}{ }^{-}\right)\right]$(2) (Reaction Scheme $3 \mathrm{c} 2$ ), $\left[\left(\mathrm{TU}_{2}\right)^{2+}\left(\mathrm{Br}^{-}\right)\left(\mathrm{I}^{-}\right)\right](4)$ (Reaction Scheme $3 \mathrm{e} 1$ or $\left.3 \mathrm{f}\right)$ and $\left[\left(\mathrm{TU}_{2}\right)^{2+}\right.$ $\left.2\left(\mathrm{Br}^{-}\right) \cdot \mathrm{H}_{2} \mathrm{O}\right](5)$ (Reaction Scheme 3e2) were formed accordingly. Excess of hydroiodic acid leads to the $\left[(\mathrm{TUH})^{+}\left(\mathrm{I}_{3}{ }^{-}\right)\right](3)$ when TU reacts with di-iodine in a $1: 1: 2$ (TU: $\left.\mathrm{I}_{2}: \mathrm{HI}\right)$ ratio (Reaction Scheme 3d). The proton excess prevents the redox reaction by stabilising the cationic species $\mathrm{TUH}^{+}$. When the product of the reaction between TU with an excess of di-iodine is crystallized in acetone-ethylether solution media, the ionic salt of formula $\left[\left(\right.\right.$ DAThd $\left.\left.^{+}\right)\left(\mathrm{I}^{-}\right)\right](6)$ (DAThd $=3,5$-diamino1,2,4-thiadiazole) is obtained (Reaction Scheme $3 \mathrm{~g}$ ) in a similar manner to the reaction shown in Scheme 2 (see the Introduction part above). ${ }^{18 b}$ This reaction involves oxidation of TU to a cationic disulphide which then is turned to the cyclic ionic compound 6 by desulfuration.

Similar to TU, methylthiourea (MeTU) is oxidized to $\left[2\left(\mathrm{MeTU}_{2}\right)^{2+} \cdot 2\left(\mathrm{Br}^{-}\right) \cdot\left(\mathrm{I}_{4}{ }^{2-}\right)\right](7)$ (Reaction Scheme $\left.3 \mathrm{~h}\right)$. The ionic salt $\left[\left(\mathrm{DMeAThH}^{+}\right)\left(\mathrm{I}^{-}\right)\left(\mathrm{H}_{2} \mathrm{O}\right)\right](8)$ (Reaction Scheme $3 \mathrm{i}$ and $3 \mathrm{k}$ ), which contains the cationic 2-amino-3,4-dimethylthiazole $\left(\mathrm{DMeAThH}^{+}\right)$, was grown from acetone solution when MeTU reacts with an excess of di-iodine, while when ethanol was used the $\left[\left(\mathrm{AMeAThdH}^{+}\right)\left(\mathrm{I}_{3}{ }^{-}\right)\right]$(9) compound (Reaction Scheme $3 \mathrm{~m})$, which contains the cationic 5-amino-3-methylamino-4-methyl-1,2,4-thiadiazole (AMe2AThdH) ${ }^{+}$, was isolated. Compound 8 was derived possibly through de-oxygenation of acetone which simultaneously reacts with the MeTU residue formed from the degradation of the corresponding disulfide dication in a similar manner to the synthetic pathway shown in Reaction Scheme 1. ${ }^{12}$ However, the isolation of compounds 6 and 9 might be due to the reaction between the residues formed from the degradation of the corresponding dicationic disulfides which have been desulfurated previously (Reaction Scheme 4). Crystals of elemental $\mathbf{S}_{\mathbf{8}}$ were also isolated from Reaction Scheme $3 \mathrm{~m}$. The isolation of elemental sulfur further supports our assumption.

The formation of $\mathbf{S}_{\mathbf{8}}$ is in accordance with the stoichiometry of the reaction and is also observed during the synthesis which involves arylothioamides in DMSO solution (Reaction Scheme 2). ${ }^{18 b}$

Johnson and Edens ${ }^{20 a}$ reacted ethylenethiourea with di-iodine in water and they formulated the (red crystalline) product as the di-sulfide. The repetition of this reaction by Herbstein and Schwotzert ${ }^{20 b}$ showed that a condensation product was unexpectedly formed, by the N-substitution of ethylenethiourea, from its desulfurated species, indicating that desulfuration of the thiol had taken place.
We have also recently shown that selenium analogues of the anti-thyroid drug 6- $n$-propyl-2-thiouracil (PTU), of formulae RSeU, [R = methyl- (Me-), ethyl- (Et-), n-propyl- ( $n$-Pr-) and i-propyl- (i-Pr-)], reacted with di-iodine in a $1: 1$ molar ratio in dichloromethane solutions and resulted in the formation of $\left[(\mathrm{RSeU}) \mathrm{I}_{2}\right] \cdot{ }^{2 g}$ Crystallization in chloroform led to the formation of the CT complex $\left[(n-\mathrm{PrSeU}) \mathrm{I}_{2}\right]$. Re-crystallization of the $\left[(\mathrm{RSeU}) \mathrm{I}_{2}\right]$ compounds in acetone gave the di-selenides of formulae $\left.[N \text {-(6-Et-4-pyrimidone)(6-Et-SeU })_{2}\right]$ and $[N-(6-n-P r-4-$ pyrimidone)(6- $n$-Pr-SeU $\left.)_{2}\right]$. Re-crystallization in methanolacetonitrile solutions, on the other hand, led to the deselenation with the formation of 6-n-propyl-2-uracil ( $n$-Pr-U). ${ }^{2 g}$ The formation of these products indicated that deselenation occurred upon reaction of selenoamides with di-iodine. ${ }^{2 g}$

Similar to deselenation, the desulfuration of 2-mercapto5 -nitrobenzimidazole upon reaction with di-iodine was also observed, producing 2-hydroxy-5-nitrobenzimidazole. ${ }^{2 k}$ This is the first reported example of such a reaction of a thiol in the presence of $I_{2}$ (Reaction Scheme 5).

\section{Solution studies}

Solution studies (UV and ${ }^{1} \mathrm{H}$-NMR) were employed for the interpretation of the species formed in solution, based on the solid-state compounds observed by XRD.

\section{NMR spectroscopy}

The ${ }^{1} \mathrm{H}-\mathrm{NMR}$ spectrum of the free ligand TU (Fig. S1†) shows resonance signals for the amine protons at $7.06 \mathrm{ppm}(\mathrm{br}$, $\mathrm{H}\left(\mathrm{NH}_{2}\right)$ ) in DMSO- $\mathrm{d}_{6}$ solution. The spectra of compounds $\mathbf{1 - 5}$, however, are dominated by two broad resonances based on the preparation procedures applied; (1_a): 7.6-7.1 and $6.19 \mathrm{ppm}$, (1_b): $8.2-7.6$ and 6.19 ppm, (1_c1): $8.4-7.2$ and 6.19 ppm, (2_c2): $8.4-7.7$ and 6.19 ppm, (4_e1): $8.8-7.8$ and 6.19, (4_f): 9.1-8.1 and 6.19, (5_e2): 8.1-7.5 and 6.19 (Fig. S1-S2†). It is therefore concluded that there exists two types of hydrogen atoms in solution in the case of 1-5 (which are varied according to the preparation method). The formation of the disulfide dication (TU $)_{2}{ }^{2+}$ is derived by lengthening of the $\mathrm{C}-\mathrm{S}$ bond and subsequently of the S-S bond (Scheme 6). Therefore, the resonance signal $6.19 \mathrm{ppm}$ is attributed to the neutral $\mathrm{H}\left(\mathrm{NH}_{2}\right)$, while signals at higher values are assigned to the $\mathrm{H}^{+}\left(\mathrm{NH}_{2}\right)$ group (Scheme 6). Moreover, variations in the resonance signals are also due to the hydrogen bonds established in solution with the oxygen of water molecules in the case of $\mathbf{1}$ and $\mathbf{5}$ or the halogen anion in all cases and those which are interacting with iodides (see Crystal structures).

The ${ }^{1} \mathrm{H}-\mathrm{NMR}$ spectrum of $\left[\left(\mathrm{DMeAThH}^{+}\right)\left(\mathrm{I}^{-}\right)\left(\mathrm{H}_{2} \mathrm{O}\right)\right]$ (8) (Fig. $\mathrm{S} 3 \dagger$ ) is dominated by two resonance signals at $(\mathbf{8} \mathbf{i})$ : 9.28 (s) and $6.69(\mathrm{~s}) \mathrm{ppm}$ and (8_k): 9.30 (s) and $6.70(\mathrm{~s}) \mathrm{ppm}$ which are attributed to the $\mathrm{H}\left(\mathrm{NH}_{2}{ }^{+}=\right)$and to the $\mathrm{H}\left(-{ }^{5} \mathrm{CH}-\right)$, while the ${ }^{1} \mathrm{H}$-NMR spectrum of the cation of $\left[\left(\mathrm{AMeAThdH}^{+}\right)\left(\mathrm{I}_{3}{ }^{-}\right)\right]$ (9) (Fig. S3†) is dominated by two resonance signals at 9.72 (s) and 7.64 (q) ppm which are attributed to the $\mathrm{H}\left(\mathrm{NH}_{2}{ }^{+}=\right)$and $\mathrm{H}\left(-\mathrm{NH}^{+}-\right)$respectively. 

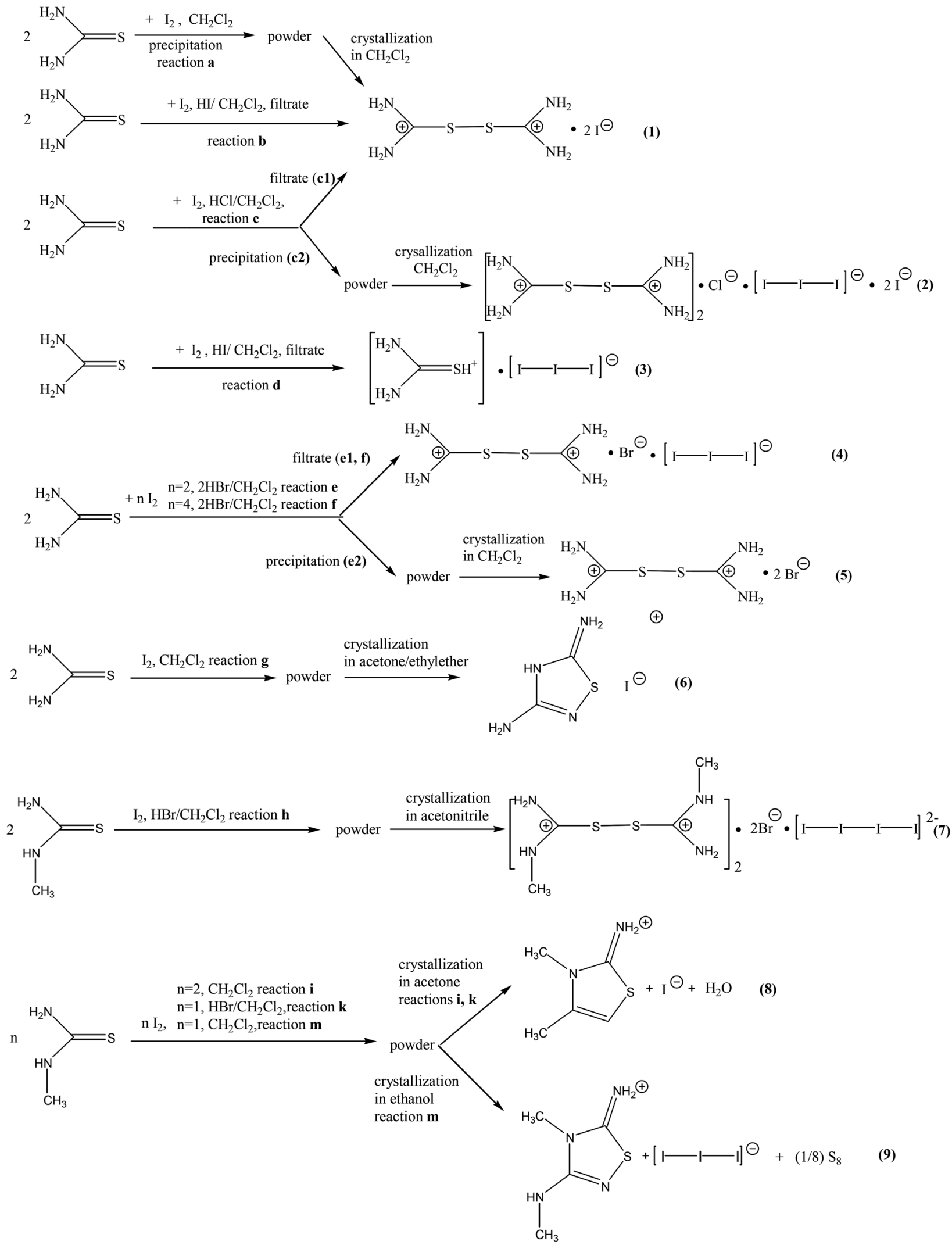

Scheme 3 


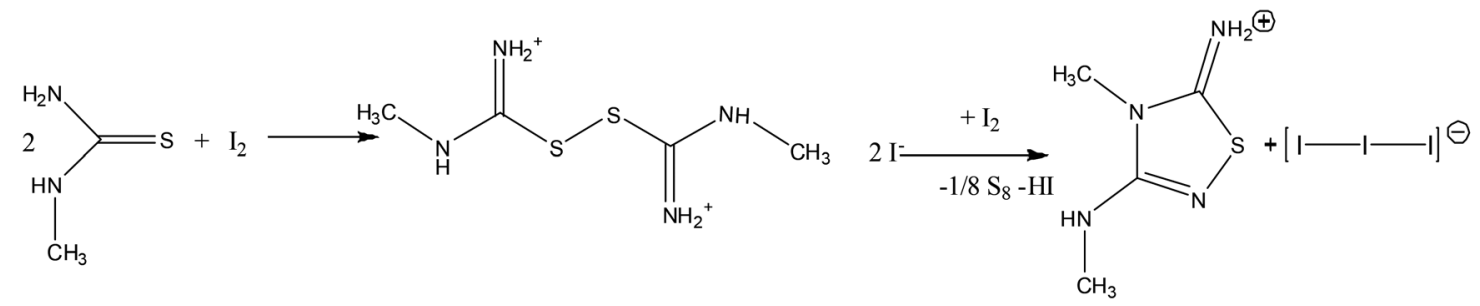

Scheme 4

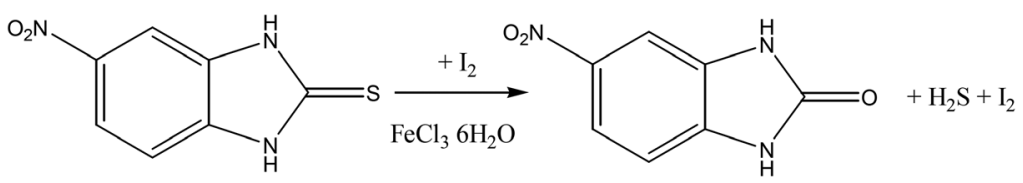

Scheme 5<smiles>N=C(N)SSC(=N)N</smiles>

\section{UV-Vis spectroscopy}

Fig. 2A shows UV spectra of thiourea and complexes 1-6. The UV-Vis spectra of the complexes were recorded in diluted dichloromethane solution $\left(5 \times 10^{-5} \mathrm{M}\right)$. Methanol $(5 \mu \mathrm{L})$ was added into each stock solution $\left(10^{-2} \mathrm{M}\right)$ in order to increase the solubility of the samples in the concentrated solution $\left(10^{-2} \mathrm{M}\right)$. The UV spectrum of TU shows an intense band at $256 \mathrm{~nm}\left(\varepsilon=3.44 \mathrm{~mol}^{-1} \mathrm{~cm}^{-1}\right)$ in $\mathrm{CH}_{2} \mathrm{Cl}_{2}$. The addition of di-iodine into dichloromethane solution of TU causes an absorbance decrease of this band and a new band at $300 \mathrm{~nm}$ (Fig. 2A) appears. In the case of compounds 2, 3, 4 and 5, a third band or shoulder also appears at $365 \mathrm{~nm}$. The spectra of compounds MeTU, 7, 8 and 9 are shown in Fig. 2B. The addition of di-iodine into dichloromethane solution of MeTU causes the appearance of a new band at $300 \mathrm{~nm}$, which is accompanied by an additional band at 365-367 $\mathrm{nm}$ in 7-9.

The band at $255 \mathrm{~nm}$ is attributed to the intra-ligand transition $\left(\pi^{*} \leftarrow \pi\right)$ (for both TU and MeTU). The absorption bands at 365 and $300 \mathrm{~nm}$ in the UV spectra of iodine compounds could be assigned to the $\mathrm{I}_{3}{ }^{-}$species $\left(\lambda_{\max }=360\right.$ and $\left.295 \mathrm{~nm}\right){ }^{2 d}$ Based on a large body of data on the CT bands of di-iodine complexes with cyclic thiourea derivatives, Laurence et al. have shown that their UV spectra constitute a CT band in the 294-302 nm range typical of planar complexes or a CT band absorbs at significantly longer wavelengths (321-350 nm) characterizing perpendicular complexes. ${ }^{21}$ Thus, among TU and MeTU complexes 1-9, the spectra of compounds 2, 3, 4, 7 and 9 show the presence of the poly-iodides anions $\mathrm{I}_{n}{ }^{-x}(n=3$
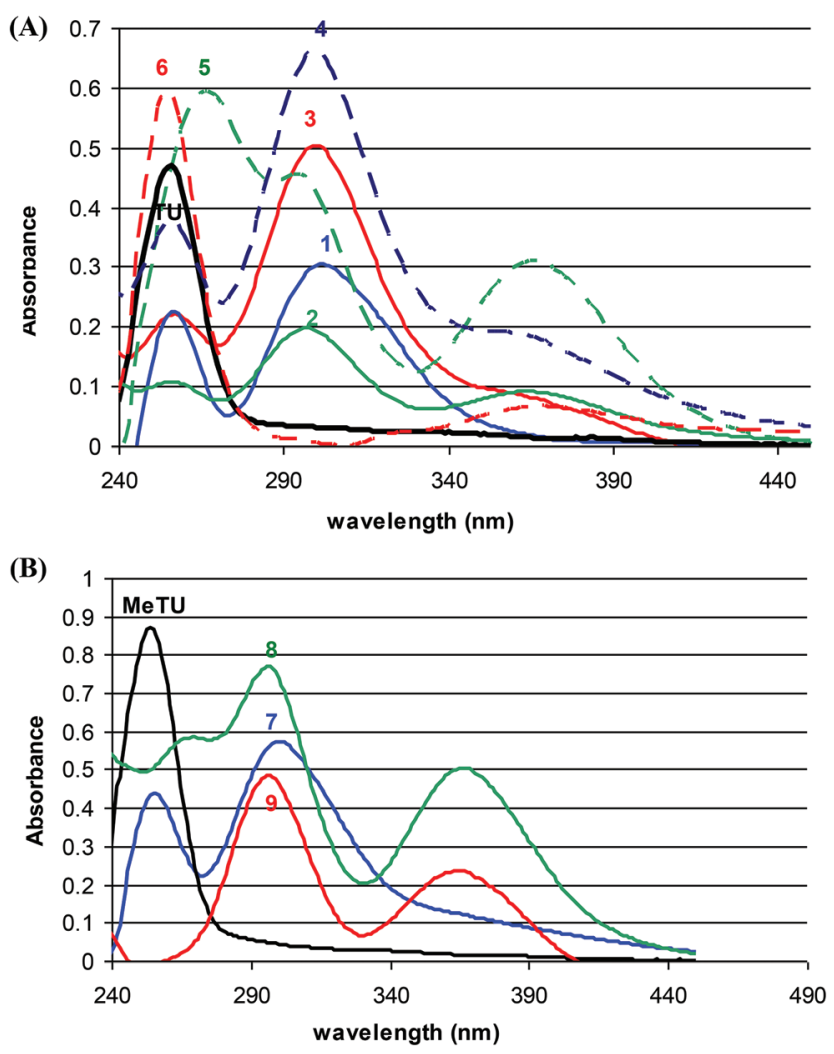

Fig. 2 (A) UV spectra of TU and its complexes 1-4 in dichloromethane (4.3 $\times 10^{-4} \mathrm{M}$ (TU), $2.0 \times 10^{-4} \mathrm{M}(1 \mathrm{a}, 1 \mathrm{c}), 2.9 \times 10^{-4} \mathrm{M}(1 \mathrm{~b}), 7.0 \times 10^{-4} \mathrm{M}(2)$, $\left.6.1 \times 10^{-4} \mathrm{M}(3), 3.1 \times 10^{-4} \mathrm{M}(4)\right)$. (B) UV spectra of MeTU and its complexes 5-6 in dichloromethane.

or 4 and $x=-1$ or -2 respectively) with a band at $300 \mathrm{~nm}$ accompanied by one band or shoulder at $365 \mathrm{~nm}$. The two absorption bands at $\lambda_{\max } 257$ and $301 \mathrm{~nm}$ in the spectrum of compound $\mathbf{1}$ where only iodide anions are present as 
counterparts of a dicationic disulfide are attributed to the dication. This is further supported by the presence of this absorption in all spectra of 1, 2, 4 and 5 which are salts containing the same dication and different anions. The spectra of the ionic heterocyclic compounds 6,8 and 9 contain absorptions at 255 and $370 \mathrm{~nm}$ (6), at 267, 299 and $367 \mathrm{~nm} \mathrm{(8)} \mathrm{and} \mathrm{at}$ 299 and $365 \mathrm{~nm}$ (9) due to the delocalized double bonds of the heterocyclic cationic ring (see Crystal structure). However the spectrum 5 is dominated by three absorption bands at 267, 296 and $366 \mathrm{~nm}$ which might be due to the stronger cationanion interaction because of the precedence of the bromide anion instead of iodide.

Crystal and molecular structures of $\left[\left(\mathrm{TU}_{2}\right)^{2+} 2\left(\mathrm{I}^{-}\right) \cdot \mathrm{H}_{2} \mathrm{O}\right](1)$, $\left[\left\{\left(\mathrm{TU}_{2}\right)^{2+}\right\}_{2} \cdot\left(\mathrm{Cl}^{-}\right) \cdot 2\left(\mathrm{I}^{-}\right) \cdot\left(\mathrm{I}_{3}{ }^{-}\right)\right](2),\left[(\mathrm{TUH})^{+}\left(\mathrm{I}_{3}{ }^{-}\right)\right](3),\left[\left(\mathrm{TU}_{2}\right)^{2+}\left(\mathrm{Br}^{-}\right)-\right.$ $\left.\left(\mathrm{I}_{3}{ }^{-}\right)\right](4),\left[\left(\mathrm{TU}_{2}\right)^{2+} 2\left(\mathrm{Br}^{-}\right) \cdot \mathrm{H}_{2} \mathrm{O}\right](5),\left[\left(\mathrm{DAThdH}^{+}\right)\left(\mathrm{I}^{-}\right)\right](6)$, $\left[2\left(\mathrm{MeTU}_{2}\right)^{2+} \cdot\left(2 \mathrm{Br}^{-}\right) \cdot\left(\mathrm{I}_{4}{ }^{2-}\right)\right](7),\left[\left(\mathrm{DMeAThH}^{+}\right)\left(\mathrm{I}^{-}\right)\left(\mathrm{H}_{2} \mathrm{O}\right)\right](8)$ and $\left[\left(\right.\right.$ AMeAThdH $\left.\left.^{+}\right)\left(\mathrm{I}_{3}{ }^{-}\right)\right](9)$

ORTEP diagrams of compounds 1-9 are shown in Fig. 3-11, while selected bond distances and angles for 1-9 are summarized in Tables 1 and 2.

Compounds 1, 2, 4 and 5 consist of one dicationic disulfide $\left[\left(\mathrm{H}_{2} \mathrm{~N}\right)_{2} \mathrm{CS}\right]_{2}{ }^{2+}$ and counter anions, depending on the

(A)

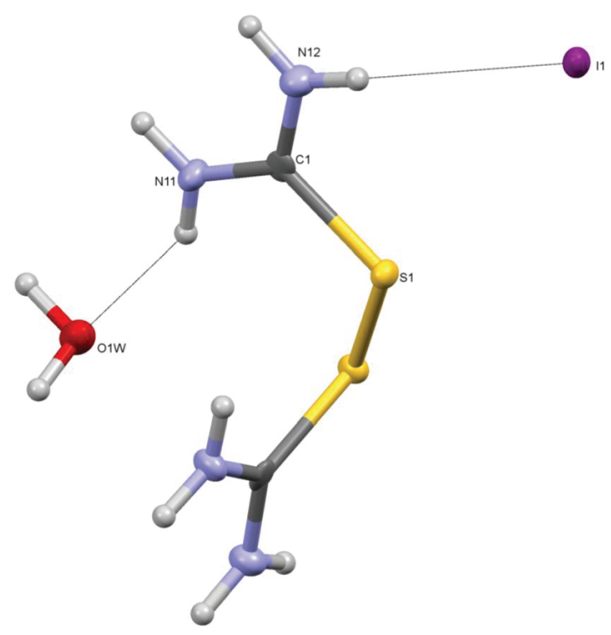

(B)

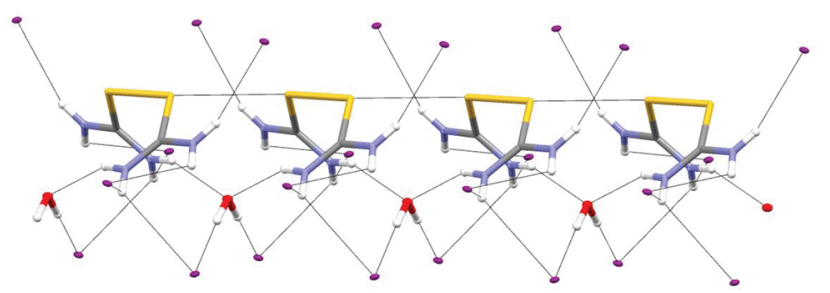

Fig. 3 (A) ORTEP diagram together with atomic numbering scheme of 1. Thermal ellipsoids drawn at the $75 \%$ probability level, hydrogen atoms are represented by spheres of arbitrary radii. Thin lines represent hydrogen bonds. The unlabeled part of the cation is related with the labeled one by symmetry operation $3 / 2-x, 3 / 2-y, z$. (B) Hydrogen bonds and $\mathrm{S}$... $\mathrm{S}$ interactions in the crystal structure of 1 .
(A)
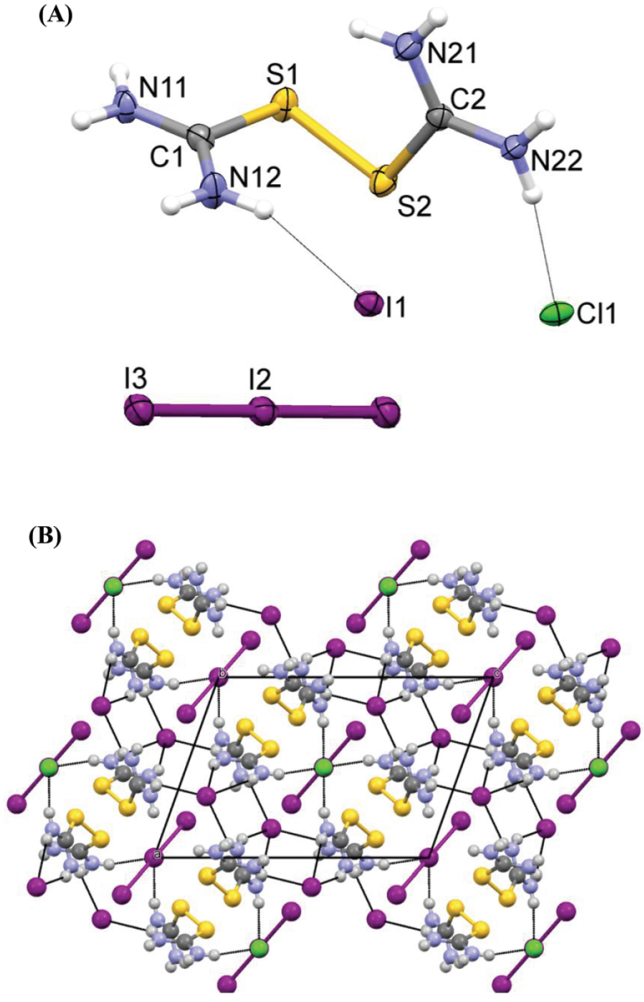

Fig. 4 (A) ORTEP diagram together with atomic numbering scheme of 2. Thermal ellipsoids drawn at the $50 \%$ probability level. Hydrogen atoms are represented by spheres of arbitrary radii. Thin lines represent hydrogen bonds. The unlabeled part of the triiodide is related with the labeled one by symmetry operation $1-x,-y-1, z$. (B) Packing along the $y$-direction in 2 with hydrogen bonds.

(A)

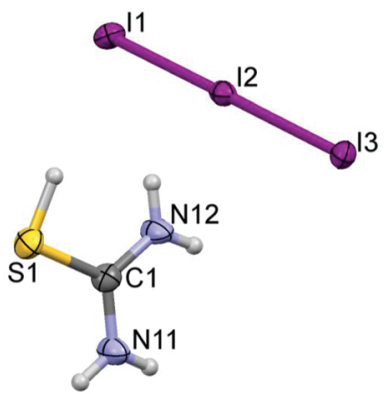

(B)

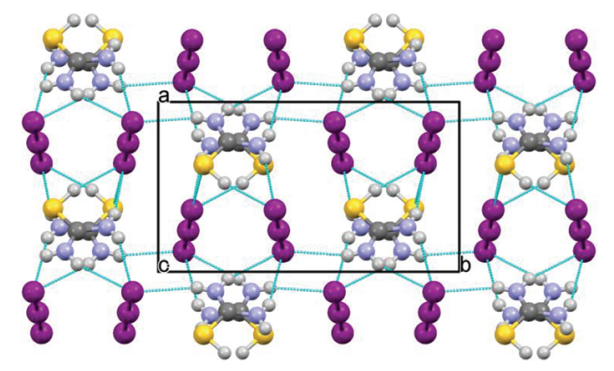

Fig. 5 (A) ORTEP diagram together with atomic numbering scheme of 3. Thermal ellipsoids drawn at the $75 \%$ probability level, hydrogen atoms are represented by spheres of arbitrary radii. (B) Packing along the $z$-direction in 3 with hydrogen bonds and S...I intermolecular interactions. 
(A)

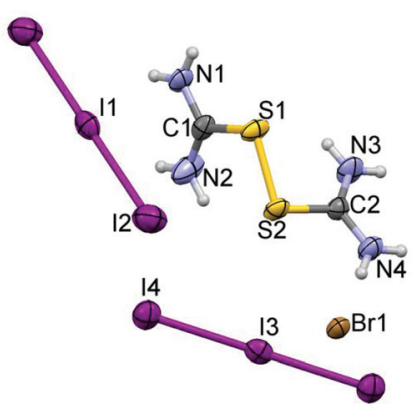

(B)

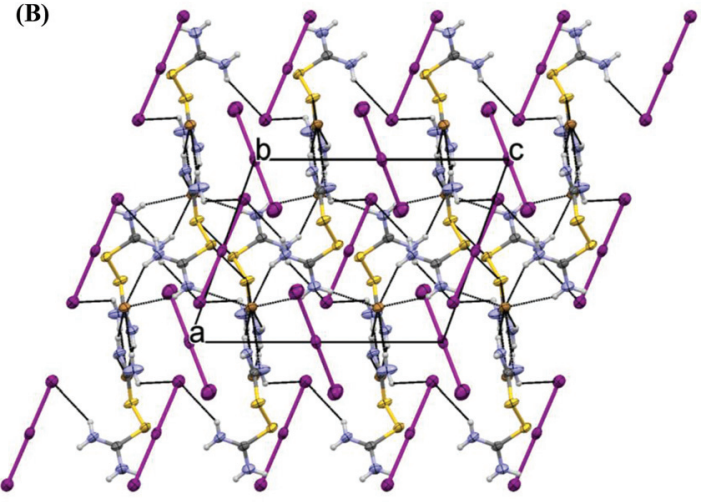

Fig. 6 (A) ORTEP diagram together with atomic numbering scheme of 4. Thermal ellipsoids drawn at the $50 \%$ probability level, hydrogen atoms are represented by spheres of arbitrary radii. The unlabeled iodine atoms are related with the labeled one by symmetry operations $2-x, 2-y, 1-$ $z$ (I2) and $1-x, 1-y, 1-z$ (14). (B) Packing diagram of 4 as seen along the $y$-direction; hydrogen bonds and short intermolecular contacts are drawn as dashed lines.

preparation conditions. Variations in both, the cationic disulfide and its counterparts, are observed. Compound 3, on the other hand, has a protonated TU ligand in the form of a $\left[\left(\mathrm{H}_{2} \mathrm{~N}\right)_{2} \mathrm{CSH}\right]^{+}$cation and a $\mathrm{I}_{3}{ }^{-}$counter anion.

Crystals of 1 derived by either Reaction Scheme 3a, 3b or $3 \mathrm{c} 1$ are identical (Fig. 3A) (small differences in the unit cell parameters in space group Pccn are caused by different data collection temperatures, and are in the range of real experimental errors: from Reaction Scheme 3a: $a=16.3940(2), b=$ $5.1170(7), c=13.3380(5) \AA, \quad R=2.74 \%$; from Reaction Scheme 3b: $a=16.3810(5), b=5.106(1), c=13.3220(4) \AA, R=$ $2.18 \%$ and from Reaction Scheme 3c1: $a=16.5130(3), b=$ 5.1450(1), $c=13.3880(2) \AA, R=4.02 \%)$. The crystal structure of complex 1 is similar to the one reported 50 years ago (space group Pccn with $a=5.15, b=16.52, c=13.39 \AA$ and $R=$ $\left.8.9 \%{ }^{22}\right)$. However, the structure of 1 reported here is superior in quality ( $R$ factor $2.18 \%$ as compared to $8.9 \%$, the former structure was based on a photographic method, hydrogen atom positions were not determined, etc.), so we decided to include its analysis here as well. Also, crystals of $\mathbf{4}$ derived from Reaction Scheme 3e1 or 3f are identical (with the same reservation as above: crystals from Reaction Scheme 3e1: $a=$ 9.8700(3), $b=12.0780(3), c=12.9330(3) \AA, \beta=109.830(3)^{\circ}, R=$ 4.55\%; crystals from Reaction Scheme 3f: $a=9.8610(8), b=$ 11.8750(9), $\left.c=12.812(1) \AA, \beta=109.250(9)^{\circ}, R=9.24 \%\right)$. Finally,
(A)
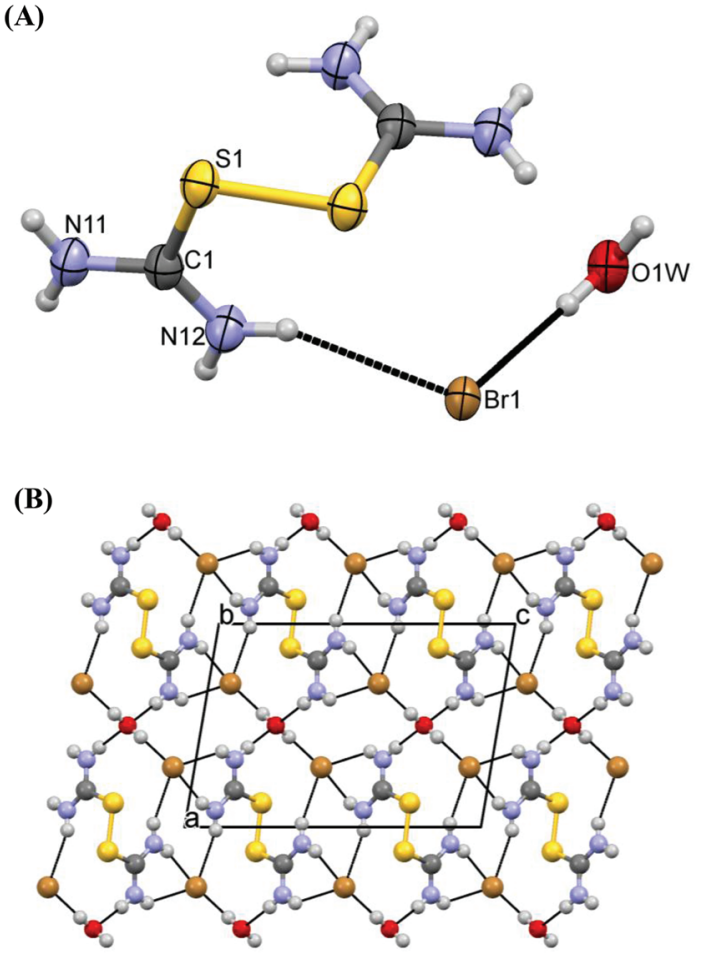

Fig. 7 (A) ORTEP diagram together with atomic numbering scheme of 5. Thermal ellipsoids drawn at the $50 \%$ probability level, hydrogen atoms are represented by spheres of arbitrary radii. Thin lines represent hydrogen bonds. The unlabeled part of the triiodide is related with the labeled one by symmetry operation $-x,-y, 3 / 2-z$. (B) Packing diagram of 4 as seen along the $y$-direction; hydrogen bonds are drawn as dashed lines.

crystals of 8 derived from Reaction Scheme $3 \mathrm{i}$ or $3 \mathrm{k}$ are identical as well (crystals from Reaction Scheme 3i: $a=7.1147(5), b=$ 8.5354(7), $c=8.7585(7) \AA, \alpha=114.807(8), \beta=91.836(6), \gamma=$ $99.090(6)^{\circ}, R=3.48 \%$; crystals from Reaction Scheme 3k: $a=$ 7.0530(4), $b=8.5000(5), c=8.6960(5) \AA, \alpha=114.890(5), \beta=$ 91.954(5), $\left.\gamma=99.007(5)^{\circ}, R=2.31 \%\right)$.

The structure of compound 1 contains one symmetrical $\left(C_{2}\right.$ symmetry) dicationic disulfide $\left[\left(\mathrm{H}_{2} \mathrm{~N}\right)_{2} \mathrm{CS}\right]_{2}{ }^{2+}$, two iodide ions as counterparts and a co-crystallized water molecule (which also lies at the two-fold axis, Fig. 3A). Strong hydrogen bonds $\mathrm{N} 11[\mathrm{H}] \cdots \mathrm{O} 1 \mathrm{~W}=2.950(4) \AA$ link the disulfide species constructing parallel 1D infinite chains (Fig. 3B). Between these chains the iodide anions are packed. In the case of $\mathbf{1}$, intermolecular S $\cdots \mathrm{S}$ interactions of 3.481(2) $\AA$ are also established (Fig. 3B). The C-S bond distance in $\mathbf{1}(\mathrm{C} 1-\mathrm{S} 1=1.783(3)$ $\AA)$ is lengthened in regard to the free ligand $\left(1.71(1) \AA^{22 a}\right)$ as expected but is close to the corresponding bond distance in the dicationic species $\left[\left(\mathrm{H}_{2} \mathrm{~N}\right)_{2} \mathrm{CS}\right]_{2}{ }^{2+}$ consisting of the

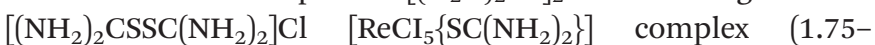
$1.76 \AA^{22 b}$ ). Thiourea moieties are planar.

The asymmetric part of the unit cell of the structure of compound 2 (Fig. $4 \mathrm{~A}$ ) contains a dicationic disulfide $\left[\left(\mathrm{H}_{2} \mathrm{~N}\right)_{2} \mathrm{CS}\right]_{2}{ }^{2+}$ and different anions: a mono-iodide, a half of a chloride and a half of a tri-iodide, which occupy special positions at two 
(A)

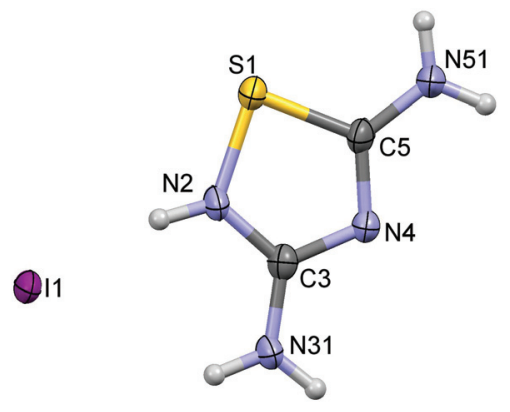

(B)

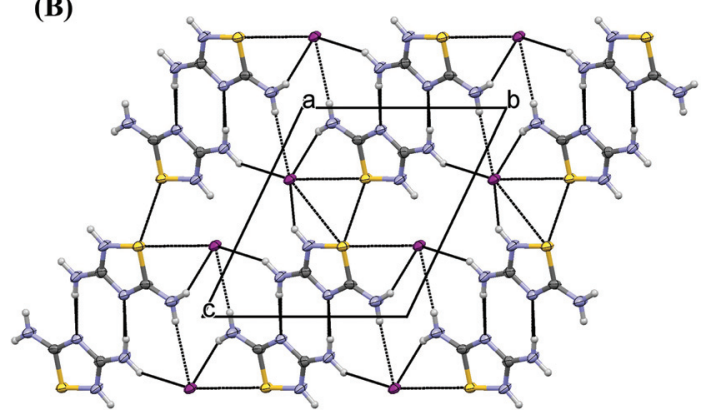

Fig. 8 (A) ORTEP diagram together with atomic numbering scheme of 6 , hydrogen atoms are represented by spheres of arbitrary radii. Thermal ellipsoids drawn at the 75\% probability level. (B) Packing diagram of 6 as seen along the $y$-direction; hydrogen bonds and short intermolecular contacts are drawn as dashed lines.

(A)

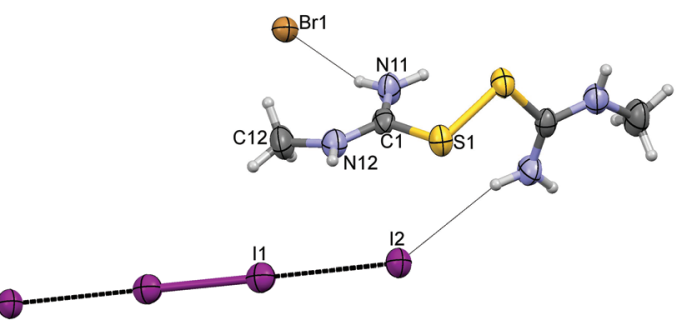

(B)

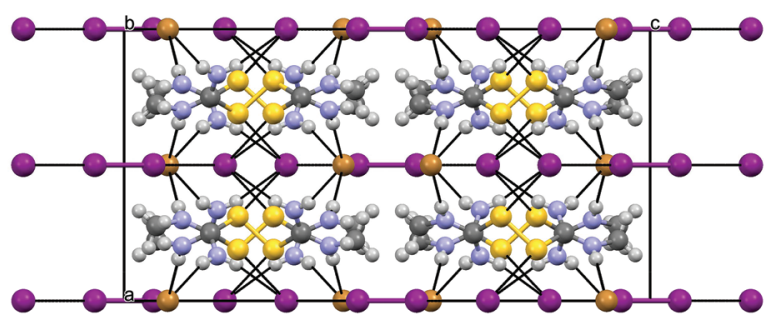

Fig. 9 (A) ORTEP diagram together with atomic numbering scheme of 7. Thermal ellipsoids drawn at the $50 \%$ probability level, hydrogen atoms are represented by spheres of arbitrary radii. Thin lines represent weaker $|\ldots|$ bond, dashed lines represent hydrogen bonds. The unlabeled part of the cation is related with the unlabeled one - by symmetry operation $x+1 / 2, y,-z+1 / 2$ while that of tetraiodide - by $-x,-y,-z$. (B) Packing diagram of 7 as seen along the $y$-direction; hydrogen bonds and short intermolecular contacts are drawn as dashed lines.
(A)

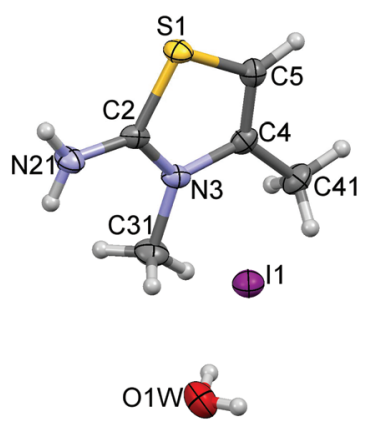

(B)

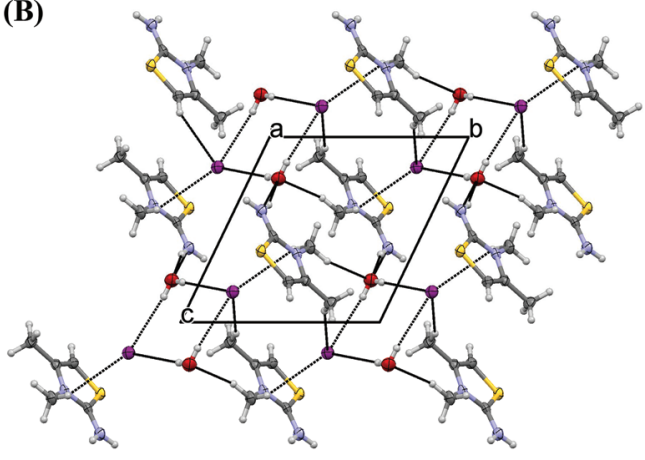

Fig. 10 (A) ORTEP diagram together with atomic numbering scheme of 8. Thermal ellipsoids drawn at the $75 \%$ probability level, hydrogen atoms are represented by spheres of arbitrary radii. (B) Packing diagram of 8 as seen along the $y$-direction; hydrogen bonds and short intermolecular contacts are drawn as dashed lines.

(A)

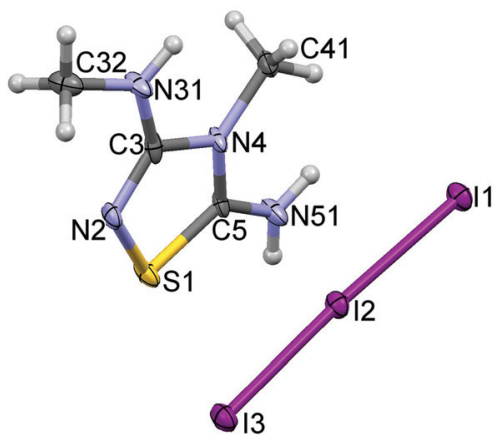

(B)

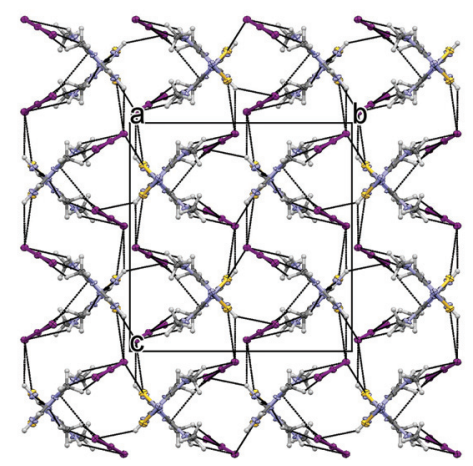

Fig. 11 (A) ORTEP diagram together with atomic numbering scheme of 9. Thermal ellipsoids drawn at the $50 \%$ probability level, hydrogen atoms are represented by spheres of arbitrary radii. (B) Packing diagram of 9 as seen along the $x$-direction; hydrogen bonds and short intermolecular contacts are drawn as dashed lines. 


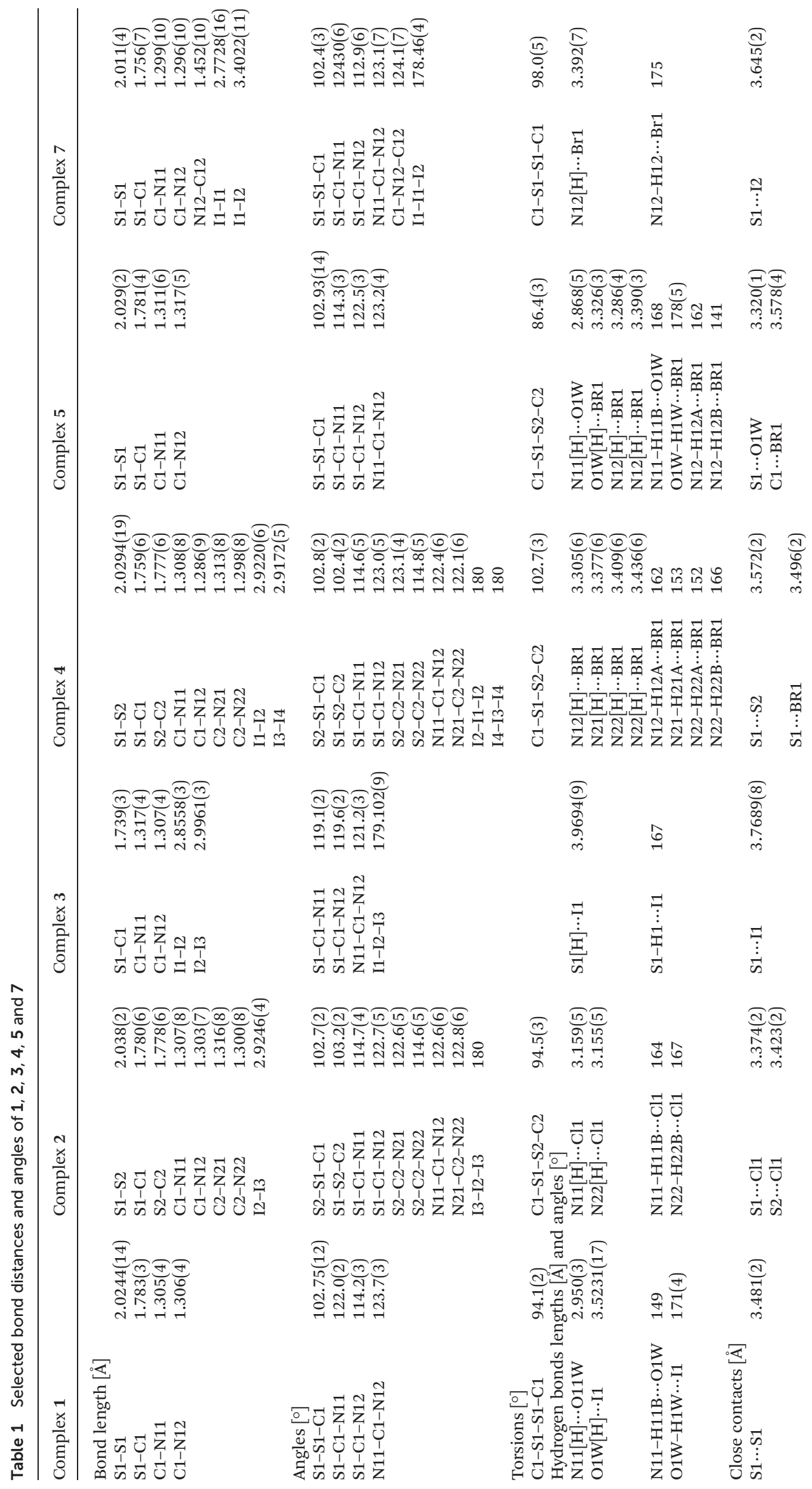


Table 2 Selected bond distances and angles of 6, 8 and 9

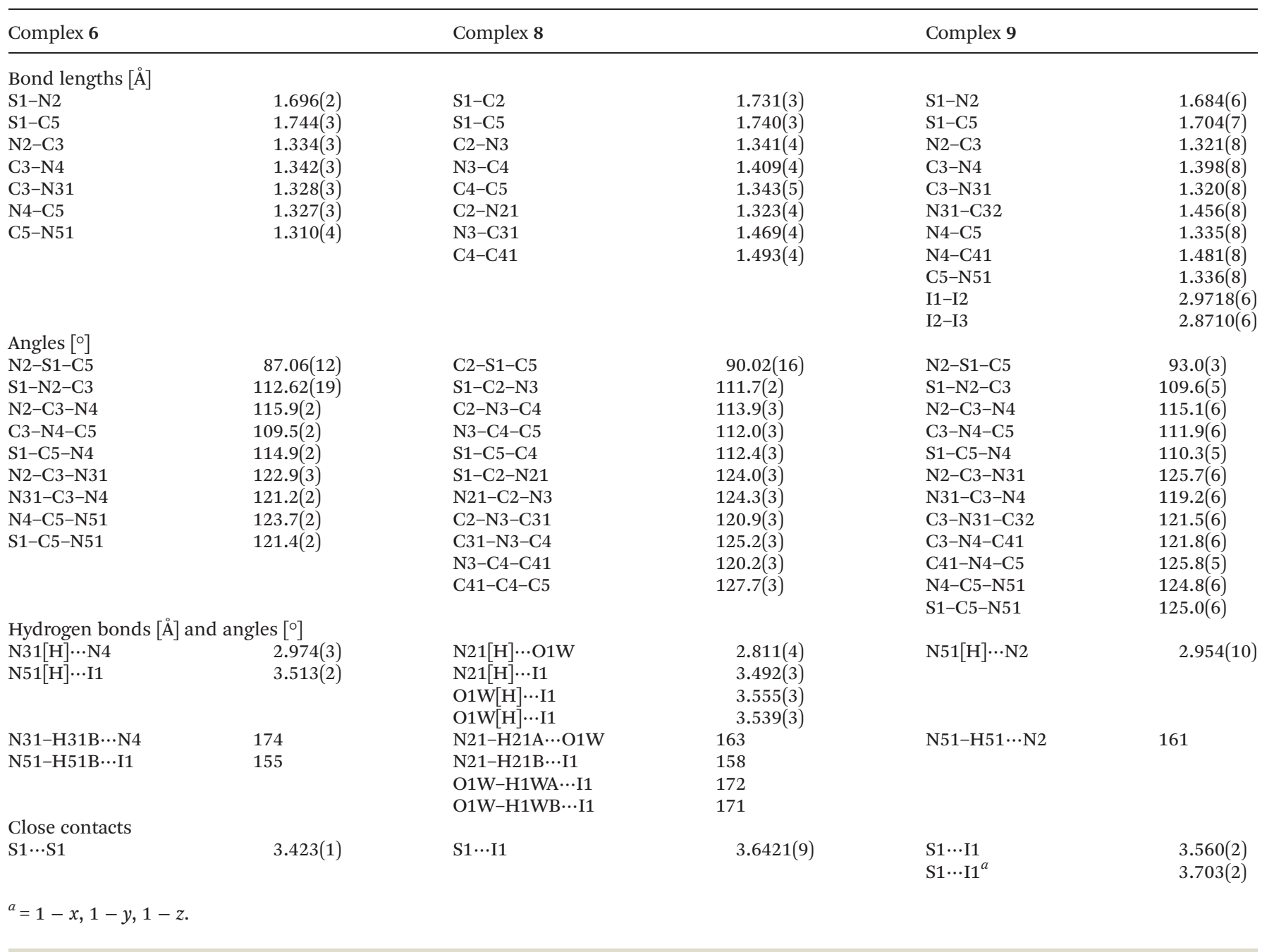

different centers of inversion: chloride at $(0,0,0)$ and triiodide at $(0,1 / 2,0)$. The dicationic disulfide species lie in parallel layers with the anions packed between these layers (Fig. 4B). The tri-iodide anion is symmetric, due to the special position it occupies, (I-I-I $\left.=180^{\circ}\right)$ with the typical length of bonds (I-I $=2.9246(4) \AA) .{ }^{6}$ Both simple anions $\left(\mathrm{Cl}^{-}\right.$and $\left.\mathrm{I}^{-}\right)$are involved in relatively stronger $(\mathrm{Cl})$ or weaker (I) $\mathrm{N}-\mathrm{H} \cdots \mathrm{X}^{-}$hydrogen bonds, while $\mathrm{I}_{3}{ }^{-}$are restrained in cavities between disulfide molecules, and do not take part in strong intermolecular interactions. It is noteworthy to mention that each chloride anion is bonded with hydrogen of four independent disulfides forming a square planar geometry around the $\mathrm{Cl}$ anion while the $\mathrm{I}^{-}$anion interacts with six N-H groups (Fig. 4B). Chloride anions are also interacting weakly with sulfur $(\mathrm{Cl} 1 \cdots \mathrm{S} 1=3.374$ (2) $\left.\AA, \mathrm{Cl} 1 \cdots \mathrm{S} 2=3.423(2) \AA,\left(\mathrm{S} 1 \cdots \mathrm{Cl} 1 \cdots \mathrm{S} 2=77.8(1)^{\circ}\right)\right)$ (Fig. 4B). The C-S bonds in $2(\mathrm{~S} 1-\mathrm{C} 1=1.780(6), \mathrm{S} 2-\mathrm{C} 2=1.778(6) \AA)$ are similar to the corresponding ones found in complex 1 . The $\mathrm{C}-\mathrm{N}$ bond distances in $2(\mathrm{C} 1-\mathrm{N} 11=1.307(8), \mathrm{C} 1-\mathrm{N} 12=1.303$ (7), C2-N21 = 1.316(8), C2-N22 = 1.300(8) $\AA$ ) are in accordance with those measured in $1(\mathrm{C} 1-\mathrm{N} 11=1.305(4) \AA, \mathrm{C} 1-\mathrm{N} 12=$ 1.306(4) ̊).
The asymmetric part of the crystal structure of compound 4, which was derived from Reaction Scheme $3 \mathrm{e} 1$ and $3 \mathrm{f}$, also contains one dicationic disulfide $\left[\left(\mathrm{H}_{2} \mathrm{~N}\right)_{2} \mathrm{CS}\right]_{2}{ }^{2+}$ moiety and two kinds of counter mono-anions: one bromide and two halves of tri-iodides (Fig. 5A). The tri-iodides are $C_{\mathrm{i}}$-symmetri$\mathrm{cal}$, their central iodine atoms lie on the centers of symmetry at $(0,0,1 / 2)$ for I1 and $(1 / 2,1 / 2,1 / 2)$ for $\mathrm{I}_{3}$. The bond lengths and angles between the carbon and sulfur atoms in $\mathbf{4}$ are similar to those of complex 1 . The $\mathrm{C}-\mathrm{S}$ bond distances in $\mathbf{4}$ (C1-S1 = 1.759(6), S2-C2 = 1.777(6) ̊) are longer than those in the free ligand (1.71(1) $\AA^{24}$ ) as expected. ${ }^{24}$ Tri-iodides are perfectly linear, due to the symmetry (I-I-I $\left.=180^{\circ}\right)$ with typical I-I bond distances $(\mathrm{I} 1-\mathrm{I} 2=2.9172(5)$ and $\mathrm{I} 3-\mathrm{I} 4=2.9220(6) \AA) .{ }^{6}$ Thiourea moieties are planar, with $\mathrm{C} 1-\mathrm{S} 1-\mathrm{S} 2-\mathrm{C} 2$ torsion angle $102.7(3)^{\circ}$. This value is closer to the corresponding one reported earlier for $\left[\mathrm{TU}_{2}\right] \mathrm{X}_{2}(\mathrm{X}=\mathrm{Cl}, \mathrm{Br}, \mathrm{I})$ by Foss et al. $\left(104.8^{\circ}\right),{ }^{22}$ but larger than the one found in $1(\mathrm{C} 1-\mathrm{S} 1-\mathrm{S} 1-\mathrm{C} 1=$ $\left.94.7(2)^{\circ}\right)$. The $\mathrm{N}[\mathrm{H}] \cdots \mathrm{Br}$ hydrogen bonds $(\mathrm{H} \cdots \mathrm{Br}$ distances of ca. $2.6 \AA$ (Table 1)) lead to an infinity plane architecture (Fig. 5B). Weaker $\mathrm{N}[\mathrm{H}] \cdots \mathrm{I} 1$ and halogen-sulfur interactions are also established. 
The asymmetric part of the unit cell of compound 5 contains a half of the dicationic disulfide $\left[\left(\mathrm{H}_{2} \mathrm{~N}\right)_{2} \mathrm{CS}\right]_{2}{ }^{2+}$, a bromide ion and half of a water molecule (Fig. 6A). The oxygen atom and the middle point of the $\mathrm{S}-\mathrm{S}$ distance lie on a two-fold axis, so the symmetry of these two species is $C_{2}$. The structure of 5 is similar to $\mathbf{1}$, with bromide counter anions instead of iodides. Strong hydrogen interactions among water molecules, bromide anions and $\mathrm{N}-\mathrm{H}$ groups create a 3D supramolecular assembly (Fig. 6B). A water molecule accepts two $\mathrm{N}-\mathrm{H} \cdots \mathrm{O}$ hydrogen bonds and acts as a donor in two $\mathrm{O}-\mathrm{H} \cdots \mathrm{Br}^{-}$hydrogen-bond interactions (Fig. 11A). Amine groups also take part in four hydrogen-bond type interaction with a bromide anion. Bromide lies in close contact with carbon $(\mathrm{C} 1 \cdots \mathrm{Br} 1=3.578(4)$ $\AA)$ and interacts with $\pi$ electrons localized on the $\mathrm{N}-\mathrm{C}-\mathrm{N}$ moiety (Fig. 11B).

The S-S bond distances found in 1-5 lie between 2.0244(14) and 2.038(2) $\AA$ (while the $\mathrm{C}-\mathrm{S}-\mathrm{S}-\mathrm{C}$ torsion angles vary from 86.4(3) to $\left.102.7(5)^{\circ}\right)$. The $S-S$ bond distances in 1-5 are shorter than those in neutral disulfides $\left\{(2 \text {-mercapto-benzoic acid })_{2}\right.$. $\left.\left.1 / 2\left(\mathrm{CH}_{3} \mathrm{CN}\right)\right\},\left\{(2 \text {-mercapto-nicotinic acid })_{2} \cdot\left(\mathrm{H}_{2} \mathrm{O}\right)\right\}\right)$ and (2-mercapto-pyrimidine $)_{2}$ which lie in the range of $2.043-2.045 \AA^{2 k}$ However, these bond lengths are closer to the corresponding $\mathrm{S}-\mathrm{S}$ distances determined in the $\left[(\mathrm{PYS}-\mathrm{PYSH})^{+} \cdot \mathrm{I}_{3}{ }^{-}\right](\mathrm{PYSH}=$ 2-mercaptopyridine $)^{2 d}$ where the mean value of the $\mathrm{S}-\mathrm{S}$ bond length in the four symmetry-independent cation-anion pairs is $2.032 \AA^{2 d}$ We have previously shown that the torsion angles are well correlated with the S-S bond lengths. ${ }^{2 j}$ Computational studies have also shown that the $\mathrm{S}-\mathrm{S}$ bonds of the disulfide molecules for the lowest energy conformation were shorter when the $\mathrm{C}-\mathrm{S}-\mathrm{S}-\mathrm{C}$ torsion angles were between 85.1 and $90^{\circ} .^{23}$ This general trend seems to be followed also in the case of structures 1-5. However, unconformities are observed for $\mathbf{5}$ which has the lowest torsion angle and for 2 with the longest bond length. These might be due to the strong $\mathrm{S} \cdots \mathrm{O}$ inter-

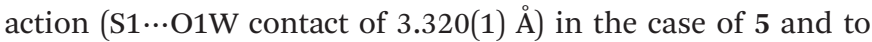
the $\mathrm{Cl} \cdots \mathrm{S}$ interactions around $3.4 \AA$ (in the case of 2 (Fig. 4B)).

The asymmetric part of the crystal structure of 7 contains a half of a $C_{2}$-symmetrical dicationic disulfide (middle point of the $\mathrm{S}-\mathrm{S}$ bond is on the two-fold axis) of (MeTU $)_{2}{ }^{2+}$, one-quarter of the tetraiodide dianion - all iodine atoms lie on the mirror plane of symmetry, and the middle point of the central I-I bond lies on the center of symmetry at $(0,0,0)$, and a half of the bromide which lies on the mirror plane of the symmetric anion (Fig. 9A). Tetraiodide is very close to linearity (I2-I1-I1 = 178.46(4) A). Disulfides are built of two methylthiourea moieties, which are planar (max deviation from the least-squares plane is 0.081(6) $\AA$ ). The S1-S1 bond length (2.011(4) $\AA$ ) is similar to the one in $\mathbf{1}(2.022(2) \AA)$, but the $\mathrm{S}-\mathrm{C}-\mathrm{C}-\mathrm{S}$ torsion angle $\left(98.0(5)^{\circ}\right)$ is slightly larger than the appropriate value in $1\left(94.7(2)^{\circ}\right)$. This might be due to the presence of an additional methyl group. Hydrogen bonding interactions of $\mathrm{N}-\mathrm{H} \cdots \mathrm{Br}$ and $\mathrm{N}-\mathrm{H}$...I type stabilize the crystal structure (Fig. 9B).

The structure of compound 3 consists of a protonated thiourea TU $\left[\left(\mathrm{H}_{2} \mathrm{~N}\right)_{2} \mathrm{CSH}\right]^{+}$and a tri-iodide counter anion $\left[\mathrm{I}_{3}{ }^{-}\right]$ (Fig. 5A). The bond lengths and angles are generally in accordance with those reported for the free ligand, ${ }^{24}$ but the $\mathrm{C}-\mathrm{S}$ bond, of $1.739(3) \AA$, is longer than that of the free ligand (1.71(1) $\AA^{24}$ ) due to the protonation of the sulfur atom. The $\mathrm{C}-\mathrm{N}$ bonds are almost equal and shorter than the corresponding bonds in a free ligand (1.33(1) $\AA^{24}$ ). The tri-iodide anion is highly asymmetrical and strictly linear (I1-I2 = $2.8558(3) \AA$ A, I2-I3 = 2.9961(3) A, I1-I2-I3 = 179.102(9) $\left.{ }^{\circ}\right)$. In the crystal, a number of hydrogen bonds accepted by the terminal iodine atoms are observed (Fig. 5B).

Crystals of 6 contain the protonated 3,5-diamino-1,2,4-thiadiazole cation (DAThd) ${ }^{+}$and an iodide counter anion (Fig. 6A). The same product was also obtained by reacting (1-diaminomethylene)thiourea with either copper(II) chloride or chromium trichloride. ${ }^{25 a}$ Comparative study of $\mathrm{C}-\mathrm{N}$ bonds in the

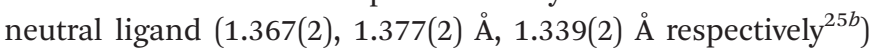
reveals that they are significantly longer than in 6 (1.334(3), 1.328(3), 1.327(3) ̊). All atoms of (DAThd) ${ }^{+}$have insignificant deviations from the plane ( $\max$ deviation of $0.015(2) \AA$ ). Strong hydrogen bonds N31N $4(1-x, 1-y, 2-z)$ link two (DAThd) ${ }^{+}$ions into centrosymmetrical pairs, while other, weaker interactions: $\mathrm{N}-\mathrm{H} \cdots \mathrm{I}$ hydrogen bonds, $\mathrm{S} \cdots \mathrm{S}$ contacts (3.423(1) $\AA$ ) create the three-dimensional structure of cations and anions.

Crystals of 8 contain a 3,4-dimethyl-2-aminothiazole $(\mathrm{DMeAThH})^{+}$cation, an iodine anion and a water molecule (Fig. 10A). The neutral 3,4-dimethyl-2-aminothiazole (DMeATh) was obtained previously by treatment of benzothiazol-2-ylamine of $\mathrm{F}_{3} \mathrm{CSO}_{3} \mathrm{Me}$ and $\mathrm{KH}$, and its crystal structure was reported. ${ }^{26}$ Significant differences are observed between the protonated $\left(\mathrm{DMeAThH}^{+}\right)$and the neutral species: the two $\mathrm{C}-\mathrm{N}$ bonds $(\mathrm{C} 2-\mathrm{N} 21=1.323(4), \mathrm{N} 3-\mathrm{C} 31=1.469(4) \AA)$ in 8 are longer than the corresponding ones found in DMeATh (1.280(3), 1.455(3) A), ${ }^{26}$ while the third $\mathrm{C}-\mathrm{N}$ bond and the $\mathrm{C}-\mathrm{S}$ bonds in $8(\mathrm{C} 2-\mathrm{N} 3=1.341(4), \mathrm{S} 1-\mathrm{C} 2=(1.731(3) \AA)$ are shorter than the corresponding ones in DMeATh (1.372(4), 1.781(3) A). ${ }^{26}$ This indicates that the positive charge is located on the $\left[\mathrm{S}-\mathrm{C}\left(\mathrm{NH}_{2}\right)=\mathrm{N}\right]^{+}$moiety (Scheme 7). However, the cation is essentially planar (max. deviation of $0.063(5) \AA$ ), which may suggest that in fact the charge is delocalized over the whole molecule.

Strong $\mathrm{N} \cdots \mathrm{I}, \mathrm{O} \cdots \mathrm{N}$ and $\mathrm{O} \cdots \mathrm{I}$ interactions join the 2D layers of cations with water molecules and iodide anions which fill the space between these layers (Fig. 10B).

The crystal structure of 9 contains protonated 5-amino-3methylamino-4-methyl-1,2,4-thiadiazole $\left[(\mathrm{AMeAThdH})^{+}\right]$and tri-iodide anions (Fig. 11A). The anion is linear (I1-I2-I3 = $\left.176.70(2)^{\circ}\right)$ and highly asymmetrical $(\mathrm{I} 1-\mathrm{I} 2=2.9718(6) \AA$ А, I2-I3 = $2.8710(6) \AA$ ). Two equal C-N bonds (1.335(8), 1.336(8) $\AA$ ) and

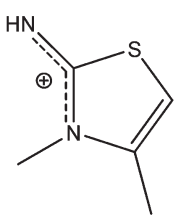

Scheme 7 


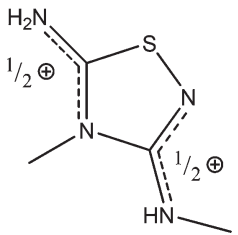

Scheme 8

one longer 1.398(8) $\AA$ are found in the thiadiazole ring. The positive charge is located on imidamide groups of N2-C3N31 and N4-C5-N51 (Scheme 8), where the shortest bonds are observed. The thiadiazole moieties are planar (max. deviation of $0.032(6) \AA)$. The N2-S1-C5 angle $\left(93.0(3)^{\circ}\right)$ in 9 is larger than the corresponding one of $5\left(\mathrm{C} 2-\mathrm{S} 1-\mathrm{C} 5=90.0(2)^{\circ}\right)$.

The strong hydrogen bond $\mathrm{N} 51[\mathrm{H}] \cdots \mathrm{N} 3=2.96(1) \AA$ creates infinite chains of cations (Fig. 11B), and between the chains there are anions, interacting with the cations by means of a weak hydrogen bond and S...I interactions (Fig. 11B).

The elemental $\mathbf{S}_{\mathbf{8}}$ crystals which happened to result from one of the reactions turned out to be those of an $\alpha$-sulfur polymorphic form (Fddd space group, $a=10.319(1), b=12.669(1)$, $c=24.321(2) \AA)$.

\section{Conclusions}

A variety of products were obtained from the reaction of diiodine with thiourea or methylthiourea. The reaction of $\mathrm{TU}$ or MeTU with di-iodine in the absence or presence of hydroiodic, hydrobromic or hydrochloric acids in $1: 1,1: 1: 1$ or $1: 1: 2$ yields ionic salts which contain dicationic disulfides (compounds $1,2,4,5$, and 7), while the type of the counter anions and the whole crystal structure of these compounds are dependent on the reaction conditions (stoichiometry, presence or absence of acid, etc). The anionic species in the crystal structures of compounds $\mathbf{1}, \mathbf{2}, \mathbf{4}$, and 5 contains iodide, tri-iodide and/or chloride and/or bromide. In the case of compound 7 the counter anion consists of the di-anionic tetra-iodide $\mathrm{I}_{4}{ }^{2-}$. By increasing the acidity however, of the media, the formation of the dicationic disulfide is prevented and the mono-cationic $\mathrm{TUH}^{+}$species precipitates (3). Cyclic compounds 6, 8 and 9 were also derived by the reaction of TU or MeTU with di-iodine followed by crystallization in polar solvent media: Thus the use of acetone leads to the formation of compound 8 which contains the 2-amino-3,4-dimethylthiazole cation from the interaction of the MeTU with the de-oxygenated solvent while by using ethanol instead, the compounds $\mathbf{6}$ and $\mathbf{9}$ are obtained, which contain the 5-amino-3-methylamino-4-methyl-1,2,4thiadiazole cation from the interaction of TU or MeTU with desulfurated reagents.

King et al. ${ }^{12}$ demonstrate that ketones react with thiourea and halogens, or certain oxidizing agents to give substituted 2-aminothiazoles through dicationic disulfide intermediate (Reaction Scheme 1). Since dicationic disulfides were isolated when TU or MeTU react with di-iodine (Reaction Scheme 3a-c,

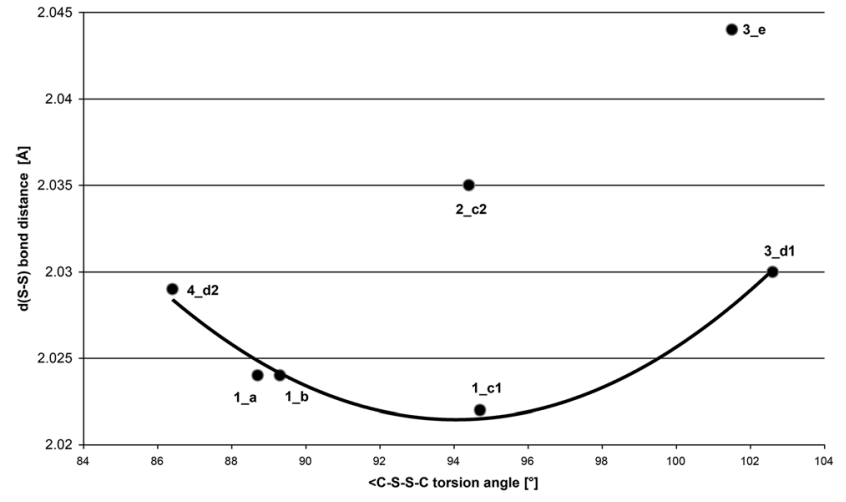

Fig. 12 Relationship between S-S bond distance vs. C-S-S-C torsion angle in compounds $1,2,4$, and $5\left(y=1.18 \times 10^{-4} x^{2}+2.23 \times 10^{-2} x+\right.$ 3.07; $\left.R^{2}=0.972\right)$.

3e-f) a similar mechanism could be assumed for the preparation of 8 . Florani et al. also reported the formation of 1,2,4thiadiazole derivatives from the reaction of arylothioamides and chloride or bromide anions and acid in DMSO (Reaction Scheme 2). ${ }^{18 b}$ This further supports our assumption of the formation of $\mathbf{6}$ and $\mathbf{9}$ through a dicationic disulfide intermediate followed by the formation of reactive radicals.

We have previously shown that a relationship between the S-S distance and torsion $\mathrm{C}-\mathrm{S}-\mathrm{S}-\mathrm{C}$ exists, ${ }^{2 j}$ which is also supported by the reported computational studies on small molecules. ${ }^{23}$ Experimental data (Fig. 12) are presented that show a hyperbola correlation is obtained by comparing $d(\mathrm{~S}-\mathrm{S})$ vs. $<(\mathrm{C}-\mathrm{S}-\mathrm{S}-\mathrm{C})$. The closer S-S distance is adopted for the best molecule conformation (minimum energy state) which in the case of $\left[\left(\mathrm{H}_{2} \mathrm{~N}\right)_{2} \mathrm{CS}\right]_{2}{ }^{2+}$ corresponds to the torsion angle C-S-S-C of $94.05^{\circ}$, and to the S-S bond length of $2.0215 \AA$. The exceptions observed in 2_c2 are attributed to the strong intermolecular interactions $\mathrm{S} \cdots \mathrm{Cl}$ which are lengthening the S-S bond distance, and in 3_e, to the low refinement (high value of the $R$ factor) of $9.24 \%$.

\section{Experimental}

\section{Materials and instruments}

All solvents used were of reagent grade. Di-iodine (Aldrich), hydroiodic acid (57\%) (Aldrich), hydrobromic acid (48\%) (Fluka), hydrochloric acid (38\%) (Merck), and thiourea methylthiourea (Merck) were used with no further purification. Melting points were measured in open tubes with a Stuart scientific apparatus and are uncorrected. Infra-red spectra in the region of $4000-400 \mathrm{~cm}^{-1}$ were obtained from $\mathrm{KBr}$ with a Perkin-Elmer Spectrum GX FT-IR spectrophotometer. The ${ }^{1} \mathrm{H}$ NMR spectra were recorded with a Bruker AC250 MHFT NMR instrument in DMSO- $\mathrm{d}_{6}$ solutions. Mass Spectra (MHRMS) were recorded in $\mathrm{MeOH}-\mathrm{CH}_{2} \mathrm{Cl}_{2}$ solutions of $200 \mu \mathrm{L} / 800 \mu \mathrm{L}$ on LTQ-ORBITRAP-XL (Thermoscientific USA) with a resolution of 10000 . 
Synthesis and crystallization of $\left[\left(\mathrm{TU}_{2}\right)^{2+} 2\left(\mathrm{I}^{-}\right) \cdot \mathrm{H}_{2} \mathrm{O}\right] \quad(\mathbf{1})$, $\left[2\left(\mathrm{TU}_{2}\right)^{2+} 2\left(\mathrm{I}^{-}\right)\left(\mathrm{I}_{3}^{-}\right) \cdot\left(\mathrm{Cl}^{-}\right)\right](2),\left[\mathrm{TUH}^{+} \cdot \mathrm{I}_{3}{ }^{-}\right](3),\left[\left(\mathrm{TU}_{2}\right)^{2+}\left(\mathrm{I}_{3}{ }^{-}\right) \cdot\left(\mathrm{Br}^{-}\right)\right]$ (4), $\left[\left(\mathrm{TU}_{2}\right)^{2+} 2\left(\mathrm{Br}^{-}\right) \cdot \mathrm{H}_{2} \mathrm{O}\right] \quad(5), \quad\left[\left(\mathrm{DAThdH}^{+}\right) \cdot\left(\mathrm{I}^{-}\right) \cdot \mathrm{H}_{2} \mathrm{O}\right] \quad(6) \quad[2$ $\left.\left(\mathrm{MeTU}_{2}\right)^{2+}\left(\mathrm{I}_{4}^{-}\right) 2\left(\mathrm{Br}^{-}\right)\right] \quad(7), \quad\left[\left(\mathrm{DMeAThH}^{+}\right)\left(\mathrm{I}^{-}\right)\left(\mathrm{H}_{2} \mathrm{O}\right)\right] \quad$ (8), $\left[\left(\right.\right.$ AMeAThd $\left.\left.\mathrm{H}^{+}\right)\left(\mathrm{I}_{3}{ }^{-}\right)\right](9)$ :

Compound 1 was prepared by mixing dichloromethane solutions of di-iodine and TU in a 1:1 molar ratio (Reaction Scheme 3a) or di-iodine, TU with hydriodic acid in a $1: 1: 1$ ratio (Reaction Scheme $3 \mathrm{~b}$ ) or di-iodine, TU with hydrochloric acid (Reaction Scheme 3c1) in a 1:1:1 molar ratio under aerobic conditions at $0{ }^{\circ} \mathrm{C}$ with continuous stirring for $2-3 \mathrm{~h}$. The solution was then filtered and the resulting powder $(\mathbf{a}, \mathbf{b}$, c1) and dark crystals (b, c1) suitable for single-crystal analysis by X-ray crystallography of the complex $\mathbf{1}$ were obtained. Powder from Reaction Scheme 3a was crystallized and also dark crystals suitable for single-crystal analysis by X-ray crystallography of complex 1 were obtained.

1: (a) Yield $87 \%$ corresponding to $22 \mathrm{mg}$ of product; m.p. $77-80{ }^{\circ} \mathrm{C}$. Elemental analysis found: C: $5.72 ; \mathrm{H}: 2.86 ; \mathrm{N}$ : 13.81; S: $15.21 \%$; calculated for $\mathrm{C}_{2} \mathrm{H}_{10} \mathrm{I}_{2} \mathrm{~N}_{4} \mathrm{OS}_{2}$ : C: 5.67; H: 2.37; $\mathrm{N}: 13.21$; S: $15.12 \%$. MID-IR (KBr) $\left(\mathrm{cm}^{-1}\right)$ : 3372.44 vs, 3306.99 vs, 3162.28 vs, 3083.46 vs, 1643.41 vs, 1615.15 vs, 1527.38 sh, $1409.22 \mathrm{~s}, 1029.92 \mathrm{w}, 734.71 \mathrm{w}, 698.99 \mathrm{~m}, 599.77 \mathrm{~m}, 552.77 \mathrm{w}$, $521.86 \mathrm{w}, 459.75 \mathrm{~m}$ (Fig. S4†). UV/Vis $\left(\mathrm{CH}_{2} \mathrm{Cl}_{2}\right): \lambda_{\max }(\log \varepsilon)=$ $257 \mathrm{~nm}$ (2.52), $300 \mathrm{~nm}(2.91) .{ }^{1} \mathrm{H}-\mathrm{NMR}$ (DMSO-d $\left.{ }_{6}\right)(\delta \mathrm{ppm})$ : 6.186 [s, 1.0], 7.1-7.6 [br, 1.0] (Fig. S1†). MS m/z: 151.01 $\left[\left(\mathrm{NH}_{2}\right)_{2} \mathrm{C}-\mathrm{S}-\mathrm{S}-\mathrm{C}\left(\mathrm{NH}_{2}\right)(=\mathrm{NH})\right]^{+}$(Fig. S12 $\left.\dagger\right)$.

(b) Yield $91 \%$ corresponding to $48 \mathrm{mg}$ of product; MID-IR $(\mathrm{KBr})\left(\mathrm{cm}^{-1}\right)$ : 3318.17 vs, 3268.85 vs, 3090.44 vs, 3043.21 vs, 1656.11 vs, $1403.69 \mathrm{~m}, 1073.03 \mathrm{w}, 697.47 \mathrm{w}, 602.08 \mathrm{~m}$, 466.99 w (Fig. S4†). UV/Vis $\left(\mathrm{CH}_{2} \mathrm{Cl}_{2}\right): \lambda_{\max }(\log \varepsilon)=(3.14)$, $300 \mathrm{~nm}$ (3.39). ${ }^{1} \mathrm{H}-\mathrm{NMR}$ (DMSO-d $\left.{ }_{6}\right)(\delta \mathrm{ppm}): 6.194$ [s, 1.0], 7.6-8.2 [br, 4.0] (Fig. S1†).

(c1) Yield 81\% corresponding to $43 \mathrm{mg}$ of product; MID-IR $(\mathrm{KBr})\left(\mathrm{cm}^{-1}\right): 3270.29 \mathrm{vs}, 3091.48 \mathrm{~s}, 1656.96 \mathrm{vs}, 1403.06 \mathrm{~s}$, $1068.73 \mathrm{w}, 701.47 \mathrm{w}, 666.71 \mathrm{w}, 602.72 \mathrm{~m}, 464.86 \mathrm{w}$ (Fig. S4†). UV/Vis $\left(\mathrm{CH}_{2} \mathrm{Cl}_{2}\right): \lambda_{\max }(\log \varepsilon)=255 \mathrm{~nm}$ (3.23), $300 \mathrm{~nm} \mathrm{(3.50).}$ ${ }^{1} \mathrm{H}-\mathrm{NMR}\left(\mathrm{DMSO}^{\mathrm{d}} \mathrm{d}_{6}\right)(\delta \mathrm{ppm}): 6.185$ [s, 1.1], 7.2-8.4 [br, 1.0] (Fig. S1 $\dagger$ ).

Compound 2 was prepared by crystallization in dichloromethane of the powder precipitates initially from Reaction Scheme 3c1. Dark crystals of the complexes suitable for singlecrystal analysis by X-ray crystallography were then grown and filtered off.

2: (c2) Yield $68 \%$ corresponding to $19 \mathrm{mg}$ of product; m.p. $70-75{ }^{\circ} \mathrm{C}$. Elemental analysis found: C: 5.12; H: 1.73; N: 11.41; S: $13.34 \%$; calculated for $\mathrm{C}_{4} \mathrm{H}_{16} \mathrm{ClI}_{5} \mathrm{~N}_{8} \mathrm{~S}_{4}$ : C: $4.93 ; \mathrm{H}$ : 1.65; N: 11.50; S: $13.16 \%$. MID-IR (KBr) $\left(\mathrm{cm}^{-1}\right): 3311.44$ vs, 3256.71 vs, 3089.54 s, 2994.70 s, 1658.78 vs, $1403.77 \mathrm{~m}$, $1191.98 \mathrm{w}, 1080.00 \mathrm{~m}, 715.25 \mathrm{w}, 666.23 \mathrm{w}, 610.20 \mathrm{~m}, 462.79 \mathrm{w}$, $412.04 \mathrm{w}$ (Fig. S5†). UV/Vis $\left(\mathrm{CH}_{2} \mathrm{Cl}_{2}\right): \lambda_{\max }(\log \varepsilon)=257 \mathrm{~nm}$ (2.69), $301 \mathrm{~nm}$ (2.95). ${ }^{1} \mathrm{H}-\mathrm{NMR}$ (DMSO-d 6 ) ( $\left.\delta \mathrm{ppm}\right): 6.189$ [s, 1.0], 7.7-8.4 [s, 4.7] (Fig. S2 $\dagger$ ). MS $m / z: 170.97\left\{\left[\left(\mathrm{NH}_{2}\right)_{2} \mathrm{C}-\mathrm{S}-\right.\right.$ $\left.\left.\mathrm{S}-\mathrm{C}\left(\mathrm{NH}_{2}\right)_{2}\right] \mathrm{H}_{2} \mathrm{O}\right\}^{+}$(Fig. S13†).

Compound 3 was prepared by mixing dichloromethane solutions of di-iodine with TU with hydroiodic acid in a $1: 1: 2$
(Reaction Scheme 3d) molar ratio under aerobic conditions at $0{ }^{\circ} \mathrm{C}$ with continuous stirring for $2-3 \mathrm{~h}$. The solution was then filtered and dark crystals suitable for single-crystal analysis by X-ray crystallography of the complex 3 were obtained.

3: (d) Yield 30\% corresponding to $68 \mathrm{mg}$ of product; m.p. $54-55{ }^{\circ}$ C. Elemental analysis found: C: 2.76; H: 1.29; N: 6.21; S: $6.78 \%$; calculated for $\mathrm{CH}_{5} \mathrm{I}_{3} \mathrm{~N}_{2} \mathrm{~S}: \mathrm{C}: 2.62 ; \mathrm{H}: 1.10 ; \mathrm{N}: 6.12$; S: 7.00\%. MID-IR (KBr) $\left(\mathrm{cm}^{-1}\right): 3311$ vs, 3256.71 vs, 1658.78 vs, $1403.77 \mathrm{~s}, 1191.98 \mathrm{w}, 1080.00 \mathrm{~m}$, (Fig. S6†). UV/Vis $\left(\mathrm{CH}_{2} \mathrm{Cl}_{2}\right)$ : $\lambda_{\max }(\log \varepsilon)=257 \mathrm{~nm}(2.59), 300 \mathrm{~nm}$ (2.95). MS $m / z: 115.03$ $\left[\left(\mathrm{NH}_{2}\right)_{2} \mathrm{C}=\mathrm{SH}\right]^{+}$(Fig. S14†).

Compound 4 was prepared by mixing dichloromethane solutions of di-iodine with TU with hydrobromic acid in $1: 1: 1$ (Reaction Scheme 3e1) or 2:1:1 (Reaction Scheme 3f) under aerobic conditions at $0{ }^{\circ} \mathrm{C}$ with continuous stirring for 2-3 h. The solution was then filtered and the resulting powder (e1) and dark crystals (e1, f) suitable for single-crystal analysis by X-ray crystallography of the complex 4 were obtained.

4: (e1) Yield $81 \%$ corresponding to $87 \mathrm{mg}$ of product; m.p. $32-35{ }^{\circ} \mathrm{C}$. Elemental analysis found: C: $3.84 ; \mathrm{H}: 1.45$; N: 9.55; S: $10.20 \%$; calculated for $\mathrm{C}_{2} \mathrm{H}_{8} \mathrm{BrI}_{3} \mathrm{~N}_{4} \mathrm{~S}_{2}$ : C: $3.92 ; \mathrm{H}: 1.31 ; \mathrm{N}$ : 9.14; S: $10.46 \%$. MID-IR (KBr) $\left(\mathrm{cm}^{-1}\right): 3329.00$ vs, $3080.72 \mathrm{~s}$, $1653.97 \mathrm{vs}, 1403.60 \mathrm{~m}, 1097.44 \mathrm{w}, 1049.64 \mathrm{w}, 704.67 \mathrm{w}, 665.93$ w, $602.79 \mathrm{~m}, 551.06 \mathrm{w}, 464.52 \mathrm{w}$ (Fig. S7†). UV/Vis $\left(\mathrm{CH}_{2} \mathrm{Cl}_{2}\right)$ : $\lambda_{\max }(\log \varepsilon)=255 \mathrm{~nm}(2.55), 300 \mathrm{~nm}(2.94) .{ }^{1} \mathrm{H}-\mathrm{NMR}$ (DMSO$\left.\mathrm{d}_{6}\right)(\delta \mathrm{ppm}): 6.192$ [s, 1.0], 7.8-8.8 [br, 7.8] (Fig. S2†). MS m/z: $170.97\left\{\left[\left(\mathrm{NH}_{2}\right)_{2} \mathrm{C}-\mathrm{S}-\mathrm{S}-\mathrm{C}\left(\mathrm{NH}_{2}\right)_{2}\right] \mathrm{H}_{2} \mathrm{O}\right\}^{+}$(Fig. S15†).

(f) Yield $83 \%$ corresponding to $43 \mathrm{mg}$ of product; MID-IR (KBr) $\left(\mathrm{cm}^{-1}\right): 3343.82$ vs, 3279.12 vs, $1656.99 \mathrm{~m}, 1403.59 \mathrm{~m}$, 1098.99 w, 1050.37 w, 710.30 w, 608.40 w, 466.29 w (Fig. S7†). UV/Vis $\left(\mathrm{CH}_{2} \mathrm{Cl}_{2}\right): \lambda_{\max }(\log \varepsilon)=257 \mathrm{~nm}(2.61), 300 \mathrm{~nm}(2.91)$. ${ }^{1} \mathrm{H}-\mathrm{NMR}\left(\mathrm{DMSO}^{\mathrm{d}}{ }_{6}\right)(\delta \mathrm{ppm}): 6.194$ [s, 1.0], 8.1-9.1 [br, 8.3] (Fig. S2 †).

Compound 5 was prepared by crystallization in dichloromethane of the powder precipitates initially from Reaction Scheme 3e2. Dark crystals of the complexes suitable for singlecrystal analysis by X-ray crystallography were then grown and filtered off.

5: (e2) Yield $49 \%$ corresponding to $18 \mathrm{mg}$ of product; m.p. 107-114 ${ }^{\circ} \mathrm{C}$. Elemental analysis found: C: $7.69 ; \mathrm{H}: 3.19$; N: 17.14; S: $19.65 \%$; calculated for $\mathrm{C}_{2} \mathrm{H}_{10} \mathrm{Br}_{2} \mathrm{~N}_{4} \mathrm{OS}_{2}$ : C: 7.28 ; $\mathrm{H}$ : 3.05; N: 16.98; S: $19.43 \%$. MID-IR (KBr) $\left(\mathrm{cm}^{-1}\right): 3326.84 \mathrm{~s}$, 3257.30 vs, 2995.56 s, 1658.62 vs, 1403.05 s, 1098.47 w, 1050.49 m, 711.27 m, 605.88 m, 465.97 m, 413.21 w (Fig. S8†). UV/Vis $\left(\mathrm{CH}_{2} \mathrm{Cl}_{2}\right): \lambda_{\max }(\log \varepsilon)=257 \mathrm{~nm}(1.69), 298 \mathrm{~nm}(2.10)$, $365 \mathrm{~nm}$ (1.70). ${ }^{1} \mathrm{H}-\mathrm{NMR}$ (DMSO-d $\left.\mathrm{d}_{6}\right)(\delta \mathrm{ppm}): 6.184$ [s, 1.0], 7.5-8.1 [br, 1.3] (Fig. S2†). MS m/z: $151.01\left[\left(\mathrm{NH}_{2}\right)_{2} \mathrm{C}-\mathrm{S}-\mathrm{S}-\mathrm{C}\right.$ $\left.\left(\mathrm{NH}_{2}\right)(=\mathrm{NH})\right]^{+}$(Fig. S16†).

Compound 6 was prepared by mixing dichloromethane solutions of di-iodine and TU in a 1:2 molar ratio (Reaction Scheme $3 g$ ). The solution was then filtered and the resulting brown powder was obtained. The powder was dissolved in ethanol afterwards and orange crystals of the compound $\mathbf{6}$ were then grown that were suitable for single-crystal analysis by X-ray crystallography. 
6: (g) Yield $46 \%$ corresponding $13 \mathrm{mg}$ of product; m.p. $126-128{ }^{\circ} \mathrm{C}$. Elemental analysis found: C: 9.43; H: 2.16; N: 23.14; S: $13.01 \%$; calculated for $\mathrm{C}_{2} \mathrm{H}_{5} \mathrm{IN}_{4} \mathrm{~S}$ : C: $9.84 ; \mathrm{H}: 2.06$; N: 22.96; S: 13.14\%. MID-IR (KBr) $\left(\mathrm{cm}^{-1}\right): 3320.24$ s, $3230.71 \mathrm{~s}$, $3176.51 \mathrm{~s}, 3105.52 \mathrm{~m}, 2975.46 \mathrm{~m}, 2917.35 \mathrm{~m}, 2855.77 \mathrm{~m}$, 1621.22 vs, $1423.49 \mathrm{~m}, 1073.30 \mathrm{w}, 968.45 \mathrm{w}, 749.99 \mathrm{~m}$, $721.66 \mathrm{w}, 594.38 \mathrm{~m}, 527.64 \mathrm{~m}, 502.34 \mathrm{w}, 408.56 \mathrm{w}$ (Fig. S9†). UV/Vis $\left(\mathrm{CH}_{2} \mathrm{Cl}_{2}\right): \lambda_{\max }(\log \varepsilon)=260 \mathrm{~nm}$ (3.03), $362 \mathrm{~nm}$ (1.78).

Compound 7 was prepared by mixing dichloromethane solutions of di-iodine and $\mathrm{TU}$ with hydrobromic acid in a 1:1:1 molar ratio (Reaction Scheme $3 \mathrm{~h}$ ). The solution was then filtered and the resulting brown powder was obtained. The powder was dissolved in acetonitrile afterwards and red crystals of the compound 7 were then grown that were suitable for single-crystal analysis by X-ray crystallography.

7: (h) Yield 79\% corresponding $17 \mathrm{mg}$ of product; m.p. 138-140 ${ }^{\circ} \mathrm{C}$. Elemental analysis found: C: 9.93; H: 2.27 ; : 10.72; S: $12.55 \%$; calculated for $\mathrm{C}_{4} \mathrm{H}_{12} \mathrm{BrI}_{2} \mathrm{~N}_{4} \mathrm{~S}_{2}$ : C: $9.35 ; \mathrm{H}$ : 2.35 ; N: $10.90 ; \mathrm{S}: 12.48 \%$. MID-IR $(\mathrm{KBr})\left(\mathrm{cm}^{-1}\right): 3157.82 \mathrm{~s}$, 3082.58 s, 2995.07 vs, 1661.64 vs, $1626.53 \mathrm{sh}, 1486.42 \mathrm{w}$, $1448.41 \mathrm{w}, 1413.71 \mathrm{w}, 1308.80 \mathrm{w}, 1164.63 \mathrm{w}, 1111.21 \mathrm{w}$, $758.82 \mathrm{w}, 412.24 \mathrm{w}$ (Fig. S10 $\dagger$ ). UV/Vis $\left(\mathrm{CH}_{2} \mathrm{Cl}_{2}\right): \lambda_{\max }(\log \varepsilon)=$ $297 \mathrm{~nm}$ (2.97), $366 \mathrm{~nm}$ (2.71).

Compound $\mathbf{8}$ was prepared by mixing dichloromethane solutions of di-iodine and MeTU in a 1:2 molar ratio (Reaction Scheme 3i) or MeTU with hydrobromic acid with a 1:1:1 molar ratio (Reaction Scheme 3k). The solution was then filtered and the resulting brown powder was obtained. The powder was dissolved in acetone afterwards and bright yellow crystals of the compound $\mathbf{8}$ were then grown that were suitable for single-crystal analysis by X-ray crystallography.

8: (i) Yield $71 \%$ corresponding to $22 \mathrm{mg}$ of product; m.p. 74-81 ${ }^{\circ} \mathrm{C}$. Elemental analysis found: C: $22.19 ; \mathrm{H}: 3.90 ; \mathrm{N}$ : 10.29; S: 11.83\%; calculated for $\mathrm{C}_{5} \mathrm{H}_{11} \mathrm{IN}_{2} \mathrm{OS}$ : C: 21.91 ; H: 4.04; N: 10.22; S: 11.70\%. MID-IR (KBr) $\left(\mathrm{cm}^{-1}\right): 3470.30$ vs, 3405.04 vs, $3079.95 \mathrm{~m}, 2011.37 \mathrm{w}, 1647.15 \mathrm{vs}, 1560.76 \mathrm{vs}, 1429.22 \mathrm{~m}$, $1402.09 \mathrm{w}, 1295.66 \mathrm{~m}, 1177.88 \mathrm{~m}, 1153.32 \mathrm{~m}, 1126.36 \mathrm{w}$, $973.57 \mathrm{w}, 834.64 \mathrm{~m}, 771.43 \mathrm{~m}, 716.06 \mathrm{w}, 600.33 \mathrm{~m}, 514.40 \mathrm{~m}$ (Fig. S9†). UV/Vis $\left(\mathrm{CH}_{2} \mathrm{Cl}_{2}\right): \lambda_{\max }(\log \varepsilon)=254 \mathrm{~nm}$ (3.07), $293 \mathrm{~nm}$ (2.08). ${ }^{1} \mathrm{H}-\mathrm{NMR}\left(\mathrm{DMSO}_{6}\right)(\delta \mathrm{ppm}): 2.226$ [s, 3.3], 3.459 [s, 2.9], 6.694 [s, 1.0], 9.282 [s, 1.9] (Fig. S3†). MS m/z: $129.05\left[\mathrm{C}_{5} \mathrm{H}_{9} \mathrm{~N}_{2} \mathrm{~S}\right]^{+}$(Fig. S17†).

(k) Yield $67 \%$ corresponding to $20 \mathrm{mg}$ of product; MID-IR $(\mathrm{KBr})\left(\mathrm{cm}^{-1}\right): 3456.88 \mathrm{vs}, 3209.17 \mathrm{~s}, 3083.26 \mathrm{~s}, 2021.25 \mathrm{w}$, 1650.08 s, $1605.21 \mathrm{~m}, 1561.87 \mathrm{~s}, 1428.63 \mathrm{~m}, 1398.46 \mathrm{~m}$, $1178.36 \mathrm{~m}, 1127.19 \mathrm{w}, 834.25 \mathrm{~m}, 773.86 \mathrm{~m}, 718.28 \mathrm{~m}$, $667.35 \mathrm{~m}, 606.42 \mathrm{~m}, 518.19 \mathrm{~m}$ (Fig. S9†). UV/Vis $\left(\mathrm{CH}_{2} \mathrm{Cl}_{2}\right): \lambda_{\max }$ $(\log \varepsilon)=297 \mathrm{~nm}$ (3.15), $366 \mathrm{~nm}$ (2.89). ${ }^{1} \mathrm{H}-\mathrm{NMR}\left(\mathrm{DMSO}_{6}\right)(\delta$ ppm): 2.229 [s, 3.2], 3.464 [s, 2.9], 6.698 [s, 1.0], 9.299 [s, 1.9] (Fig. S3†).

Compound 9 was prepared by mixing dichloromethane solutions of di-iodine and MeTU in a 1:1 molar ratio (Reaction Scheme $3 \mathrm{~m}$ ). The solution was then filtered and the resulting brown powder was obtained. The powder was dissolved in ethanol afterwards and red crystals of the compound
9 suitable for single-crystal analysis by X-ray crystallography were grown among with crystals of $\mathbf{S}_{\mathbf{8}}$ as well. ${ }^{27}$

9: (m) Yield 94\% corresponding to $28 \mathrm{mg}$ of product; m.p. 154-158 ${ }^{\circ} \mathrm{C}$. Elemental analysis found: C: $23.51 ; \mathrm{H}: 3.67 ; \mathrm{N}$ : 10.91; S: $12.27 \%$; calculated for $\mathrm{C}_{5} \mathrm{H}_{9} \mathrm{IN}_{2} \mathrm{~S}: \mathrm{C}: 23.45 ; \mathrm{H}: 3.54 ; \mathrm{N}$ : 10.94; S: 12.52\%. MID-IR (KBr) $\left(\mathrm{cm}^{-1}\right): 3295.96 \mathrm{~m}, 3075.21 \mathrm{~m}$, $1620.63 \mathrm{vs}, 1522.51 \mathrm{~m}, 1410.62 \mathrm{~m}, 1383.62 \mathrm{w}, 1225.88 \mathrm{w}$, $1151.58 \mathrm{w}, 1000.05 \mathrm{w}, 889.23 \mathrm{~m}, 696.16 \mathrm{~m}, 588.46 \mathrm{w}, 522.65 \mathrm{~m}$ (Fig. S11†). UV/Vis $\left(\mathrm{CH}_{2} \mathrm{Cl}_{2}\right): \lambda_{\max }(\log \varepsilon)=297 \mathrm{~nm}(2.25)$, $365 \mathrm{~nm}$ (1.93). ${ }^{1} \mathrm{H}-\mathrm{NMR}$ (DMSO-d $\left.{ }_{6}\right)(\delta \mathrm{ppm}): 2.821$ [d, 3.5], 3.413 [s, 3.3], 7.637 [q, 1.0], 9.726 [s, 2.1] (Fig. S3†). MS m/z: $145.05\left[\mathrm{C}_{4} \mathrm{H}_{9} \mathrm{~N}_{4} \mathrm{~S}\right]^{+}$(Fig. S18 $\dagger$ ).

\section{Crystal data}

Data for compounds studied were collected by the $\omega$ scan technique: for $1 \mathrm{a}, \mathbf{1 b}, \mathbf{1 c 1}, \mathbf{2 c 2}, \mathbf{4 e 1}, \mathbf{4 f}, 5 \mathrm{e} 2$ and $\mathbf{8 i}$ on a Supernova diffractometer with Atlas CCD detector using graphite-filtered $\mathrm{CuK}_{\alpha .}(\lambda=1.5418 \AA)$ radiation and for $\mathbf{3 d}, \mathbf{6 g}, \mathbf{7 h}, \mathbf{8 k}, \mathbf{9 m}$, and $\mathbf{S}_{\mathbf{8}}$ on an XCALIBUR diffractometer with EOS CCD detector using graphite-filtered $\operatorname{MoK}_{\alpha .}(\lambda=0.71073 \AA)$ radiation.

Cell parameters for 1-9 were determined by least-squares fit. All data were corrected for Lorentz-polarization effects and absorption. ${ }^{28 a}$ The structures were solved with direct methods with SIR92 $2^{28 b}$ and refined by full-matrix least-squares procedures on $F^{2}$ with SHELXL97. ${ }^{28 c}$ All non-hydrogen atoms were refined anisotropically, and hydrogen atoms were located at calculated positions and refined as a 'riding model' with isotropic thermal parameters fixed at 1.2 times the $U_{\text {eq' }}$ 's of the appropriate carrier atom. The structure of 2 has been refined as twinned (using HKLF 5 command), and the data were reduced as twinned. The BASF factor was refined at 0.78 .

1: (a) Formula $\mathrm{C}_{2} \mathrm{H}_{10} \mathrm{I}_{2} \mathrm{~N}_{4} \mathrm{OS}_{2}, M_{\mathrm{W}}=424.06$, orthorhombic, space group Pccn, $a=16.3810(5), b=5.106(1), c=13.3220(4) \AA$, $V=1114.27(5) \AA^{3}, Z=4, T=120(1) \mathrm{K}, \rho$ (calc.) $=2.53 \mathrm{~g} \mathrm{~cm}^{-3}, \mu=$ $47.57 \mathrm{~mm}^{-1}, F(000)=784.2598$ reflections measured up to $2 \theta=75.5^{\circ}$, of which 1128 symmetry independent $\left(R_{\text {int }}=\right.$ $1.80 \%)$ and 1068 with $I>2 \sigma(I)$. The refinement converged to final $R=2.18 \%[I>2 \sigma(I)], \mathrm{w} R_{2}=5.90 \%$ (all reflections),

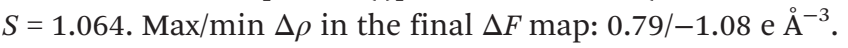

(b) Formula $\mathrm{C}_{2} \mathrm{H}_{10} \mathrm{I}_{2} \mathrm{~N}_{4} \mathrm{OS}_{2}, M_{\mathrm{W}}=424.06$, orthorhombic, space group Pccn, $a=16.3810(5), b=5.106(1), c=13.3220(4) \AA$, $\alpha=90, \beta=90, \gamma=90^{\circ}, V=1114.27(5) \AA^{3}, Z=4, T=130.0(1) \mathrm{K}$, $\rho$ (calc. $)=2.476 \mathrm{~g} \mathrm{~cm}^{-3}, \mu=47.573 \mathrm{~mm}^{-1}, F(000)=784$. The refinement converged to final $R=2.18 \%$ [for 1137 reflections with $I>2 \sigma(I)], \mathrm{w} R=5.90 \%$ (all 1178 reflections).

(c1) Formula $\mathrm{C}_{2} \mathrm{H}_{10} \mathrm{I}_{2} \mathrm{~N}_{4} \mathrm{OS}_{2}, M_{\mathrm{W}}=424.06$, orthorhombic, space group Pccn, $a=16.5130(3), b=5.1450(1), c=13.3880(2)$ $\AA, \alpha=90, \beta=90, \gamma=90^{\circ}, V=1137.44(3) \AA^{3}, Z=4, T=293(2) \mathrm{K}$, $\rho$ (calc. $)=2.476 \mathrm{~g} \mathrm{~cm}^{-3}, \mu=46.604 \mathrm{~mm}^{-1}, F(000)=784$. The refinement converged to final $R=4.02 \%$ [for 1068 reflections with $I>2 \sigma(I)]$, wR $=10.11 \%$ (all 1128 reflections).

2: (c2) Formula $\mathrm{C}_{4} \mathrm{H}_{16} \mathrm{ClI}_{5} \mathrm{~N}_{8} \mathrm{~S}_{4}, M_{\mathrm{W}}=974.44$, monoclinic, space group $P 2(1) / n, a=9.6516(3), b=9.7546(2), c=13.8230(5)$, $\beta=109.653(4)^{\circ}, V=1225.59(6) \AA^{3}, Z=2, T=130(1) \mathrm{K}, \rho$ (calc. $)=$ $2.64 \mathrm{~g} \mathrm{~cm}^{-3}, \mu=54.08 \mathrm{~mm}^{-1}, F(000)=884$. 8852 reflections 
measured up to $2 \theta=75.5^{\circ}$, of which 2538 were symmetry independent $\left(R_{\mathrm{int}}=3.52 \%\right)$ and 2400 had $I>2 \sigma(I)$. The refinement converged to final $R=4.44 \%[I>2 \sigma(I)], \mathrm{w} R_{2}=13.78 \%$ (all reflections), $S=1.099$. $\mathrm{Max} / \min \Delta \rho$ in the final $\Delta F$ map: $2.74 /$ -1.40 e $\AA^{-3}$.

3: (d) Formula $\mathrm{CH}_{5} \mathrm{I}_{3} \mathrm{~N}_{2} \mathrm{~S}, M_{\mathrm{W}}=457.83$, monoclinic, space group $P 2_{1} / c, a=7.5529(2), b=13.2275(4), c=9.1452(2), \beta=$ 98.689(2) ${ }^{\circ}, V=903.17(4) \AA^{3}, Z=4, T=295(2) \mathrm{K}, \rho$ (calc.) $=$ $3.37 \mathrm{~cm}^{-3}, \mu=10.53 \mathrm{~mm}^{-1}, F(000)=800.10478$ reflections measured up to $2 \theta=28.3^{\circ}$, of which 2060 were symmetry independent $\left(R_{\text {int }}=2.22 \%\right)$ and 1931 had $I>2 \sigma(I)$. The refinement converged to final $R=1.67 \%[I>2 \sigma(I)], \mathrm{w} R_{2}=3.83 \%$ (all reflections), $S=1.180$. $\mathrm{Max} / \min \Delta \rho$ in the final $\Delta F$ map: $0.72 /$ -0.78 e $\AA^{-3}$.

4: (e1) Formula $\mathrm{C}_{2} \mathrm{H}_{8} \mathrm{BrI}_{3} \mathrm{~N}_{4} \mathrm{~S}_{2}, M_{\mathrm{W}}=612.85$, monoclinic, space group $P 21 / c, a=9.8698(2), b=12.0775(3), c=12.9332(3)$ $\AA$, $\beta=109.830(3), V=1450.25(6) \AA^{3}, Z=4, T=293(2) \mathrm{K}, \rho$ (calc.) $=2.807 \mathrm{~g} \mathrm{~cm}^{-3}, \mu=56.46 \mathrm{~mm}^{-1}, F(000)=1096.13296$ reflections measured up to $2 \theta=75.5^{\circ}$, of which 2968 symmetry independent $\left(R_{\mathrm{int}}=5.43 \%\right)$ and 2800 with $I>2 \sigma(I)$. The refinement converged to final $R=4.27 \%[I>2 \sigma(I)], \mathrm{w} R_{2}=11.79 \%$ (all reflections), $S=1.050$. Max $/ \min \Delta \rho$ in the final $\Delta F$ map: $1.77 /$ -1.67 e $\AA^{-3}$.

(f) Formula $\mathrm{C}_{2} \mathrm{H}_{8} \mathrm{BrI}_{3} \mathrm{~N}_{4} \mathrm{~S}_{2}, M_{\mathrm{W}}=612.85$, monoclinic, space group $P 21 / c, a=9.8610(8), b=11.8750(9), c=12.812(1) \AA, \beta=$ 109.250(9) ${ }^{\circ}, V=1416.4(2) \AA^{3}, Z=4, T=130 \mathrm{~K}, \rho($ calc. $)=2.874 \mathrm{~g}$ $\mathrm{cm}^{-3}, \mu=57.815 \mathrm{~mm}^{-1}, F(000)=1096$. The refinement converged to final $R=9.24 \%$ [for 2303 reflections with $I>2 \sigma(I)$ ], $\mathrm{w} R=24.73 \%$ (all 2795 reflections).

5: (e2) Formula $\mathrm{C}_{2} \mathrm{H}_{10} \mathrm{Br}_{2} \mathrm{~N}_{4} \mathrm{OS}_{2}, M_{\mathrm{W}}=330.08$, monoclinic, space group $P 2 / c, a=8.6389(11), b=5.0436(6), c=12.3817(16)$ $\AA, \beta=99.551(12)^{\circ}, V=532.01(12) \AA^{3}, Z=2, T=130(1) \mathrm{K}$, $\rho$ (calc.) $=2.061 \mathrm{~g} \mathrm{~cm}^{-3}, \mu=13.05 \mathrm{~mm}^{-1}, F(000)=320.3184$ reflections measured up to $2 \theta=75.75^{\circ}$, of which 1098 were symmetry independent $\left(R_{\mathrm{int}}=2.70 \%\right)$ and 1047 had $I>$ $2 \sigma(I)$. The refinement converged to final $R=3.96 \%[I>2 \sigma(I)]$, $\mathrm{W} R_{2}=12.21 \%$ (all reflections), $S=1.185$. Max $/ \mathrm{min} \Delta \rho$ in the

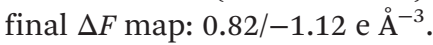

6: (g) Formula $\mathrm{C}_{2} \mathrm{H}_{5} \mathrm{IN}_{4} \mathrm{~S}, M_{\mathrm{W}}=244.06$, monoclinic, space group $P \overline{1}, a=4.5455(2), b=8.6436(3), c=9.5497(3) \AA, \alpha=$ 113.700(3), $\beta=94.020(3), \gamma=103.347(3)^{\circ}, V=328.64(2) \AA^{3}, Z=$ $2, T=100(1) \mathrm{K}, \rho$ (calc.) $=2.466 \mathrm{~g} \mathrm{~cm}^{-3}, \mu=5.09 \mathrm{~mm}^{-1}, F(000)=$ 228. 4992 reflections measured up to $2 \theta=28.0^{\circ}$, of which 1433 symmetry independent $\left(R_{\text {int }}=1.99 \%\right)$ and 1362 with $I>2 \sigma(I)$. The refinement converged to final $R=1.73 \%[I>2 \sigma(I)], \mathrm{w} R_{2}=$ $4.19 \%$ (all reflections), $S=1.073$. Max $/ \min \Delta \rho$ in the final $\Delta F$ map: $1.15 /-0.51$ e $\AA^{-3}$.

7: (h) Formula $\mathrm{C}_{4} \mathrm{H}_{12} \mathrm{BrI}_{2} \mathrm{~N}_{4} \mathrm{~S}_{2}, M_{\mathrm{W}}=514.01$, orthorhombic, space group Cmca, $a=11.3150(13), b=11.134(2), c=21.9321$ (15) $\AA, V=2763.0(7) \AA^{3}, Z=8, T=295(2) \mathrm{K}, \rho$ (calc.) $=2.471 \mathrm{~g}$ $\mathrm{cm}^{-3}, \mu=7.72 \mathrm{~mm}^{-1}, F(000)=1896.8716$ reflections measured up to $2 \theta=29.2^{\circ}$, of which 1799 were symmetry independent $\left(R_{\text {int }}=4.95 \%\right)$ and 1345 had $I>2 \sigma(I)$. The refinement converged to final $R=4.88 \%[I>2 \sigma(I)], \mathrm{w} R_{2}=13.11 \%$ (all reflections), $S=1.087$. Max $/ \min \Delta \rho$ in the final $\Delta F$ map: $1.96 /$ -1.07 e $\AA^{-3}$.
8: (i) Formula $\mathrm{C}_{5} \mathrm{H}_{11} \mathrm{IN}_{2} \mathrm{OS}, M_{\mathrm{W}}=274.12$, triclinic, space group $P \overline{1}, a=7.0530(4), b=8.5003(5), c=8.6957(5) \AA, \alpha=$ 114.890(5), $\beta=91.954(5), \gamma=99.007(5){ }^{\circ}, V=464.16(5) \AA^{3}, Z=2$, $T=100(1) \mathrm{K}, \rho$ (calc.) $=1.961 \mathrm{~g} \mathrm{~cm}^{-3}, \mu=3.62 \mathrm{~mm}^{-1}, F(000)=$ 264. 3173 reflections measured up to $2 \theta=28.0^{\circ}$, of which 1893 symmetry independent $\left(R_{\text {int }}=1.94 \%\right)$ and 1814 with $I>2 \sigma(I)$. The refinement converged to final $R=2.29 \%[I>2 \sigma(I)], \mathrm{w} R_{2}=$ $6.10 \%$ (all reflections), $S=1.081$. Max/min $\Delta \rho$ in the final $\Delta F$ map: $0.77 /-0.55$ e $\AA^{-3}$.

(k) Formula $\mathrm{C}_{5} \mathrm{H}_{11} \mathrm{IN}_{2} \mathrm{OS}, M_{\mathrm{W}}=274.12$, triclinic, space group $P \mathrm{~N}, a=7.0530(4), b=8.5000(5), c=8.6960(5) \AA, \alpha=$ 114.890(5), $\beta=91.954(5), \gamma=99.007(5) \circ, V=464.16(5) \AA^{3}, Z=$ $2, T=100.0(1) \mathrm{K}, \rho$ (calc.) $=1.961 \mathrm{~g} \mathrm{~cm}{ }^{-3}, \mu=3.619 \mathrm{~mm}^{-1}$, $F(000)=264$. The refinement converged to final $R=2.31 \%$ [for 1814 reflections with $I>2 \sigma(I)], \mathrm{w} R=6.22 \%$ (all 1893 reflections).

9: (m) Formula $\mathrm{C}_{5} \mathrm{H}_{9} \mathrm{IN}_{2} \mathrm{~S}, M_{\mathrm{W}}=256.10$, orthorhombic, space group Pbca, $a=12.6402(4), b=13.7770(8), c=14.1348(5)$ $\AA, V=2461.49(18) \AA^{3}, \mathrm{Z}=8, T=100(1) \mathrm{K}, \rho($ calc. $)=2.838 \mathrm{~g}$ $\mathrm{cm}^{-3}, \mu=7.75 \mathrm{~mm}^{-1}, F(000)=1888.6414$ reflections measured up to $2 \theta=28.1^{\circ}$, of which 2547 were symmetry independent $\left(R_{\text {int }}=4.27 \%\right)$ and 1990 had $I>2 \sigma(I)$. The refinement converged to final $R=3.67 \%[I>2 \sigma(I)], \mathrm{w} R_{2}=7.16 \%$ (all reflections), $S=1.040$. Max/min $\Delta \rho$ in the final $\Delta F$ map: $1.38 /$

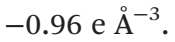

$\mathbf{S}_{\mathbf{8}}$ : (m) Formula $\mathbf{S}_{\mathbf{8}}, M_{\mathrm{W}}=256.48$, orthorhombic, space group Fddd, $a=10.319(1), b=12.669(1), c=24.321(2) \AA, \alpha=$ 90.0, $\beta=90.0, \gamma=90.0^{\circ}, V=3179.4(5) \AA^{3}, Z=16, T=100.0(1)$ $\mathrm{K}, \rho$ (calc. $)=2.143 \mathrm{~g} \mathrm{~cm}^{-3}, \mu=2.142 \mathrm{~mm}^{-1}, F(000)=2048$. The refinement converged to final $R=3.13 \%$ [for 900 reflections with $I>2 \sigma(I)], \mathrm{w} R=8.44 \%$ (all 779 reflections).

\section{Acknowledgements}

This work was carried out in partial fulfillment of the requirements for the M.Sc. theses of M. B. and carried out in both Universities of Ioannina-Greece and A. Mickiewicz-Poland within the framework of the ERASMUS program. A. M. O. is a scholar of the project "Scholarship support for Ph.D. students specializing in majors strategic for Wielkopolska's development”, sub-measure 8.2.2 Human Capital Operational Programme, co-financed by European Union under the European Social Fund. A. M. O. is also supported by the Adam Mickiewicz Foundation during the academic year 2013/2014 which is acknowledged. S.K.H. would like to thank the Unit of Environmental, Organic and Biochemical high resolution analysisORBITRAP-LC-MS of the University of Ioannina for providing access to the facilities.

\section{References}

1 (a) P. D. Boyle and S. M. Godfrey, Coord. Chem. Rev., 2001, 223, 265-299; (b) P. Deplano, J. R. Ferraro, M. L. Mercuri and E. F. Trogu, Coord. Chem. Rev., 1999, 188, 71-95. 
2 (a) G. J. Corban, S. K. Hadjikakou, A. C. Tsipis, M. Kubicki, T. Bakas and N. Hadjiliadis, New J. Chem., 2011, 35, 213224; (b) V. Daga, S. K. Hadjikakou, N. Hadjiliadis, M. Kubicki, J.H.Z. dos Santos and I.S. Butler, Eur. J. Inorg. Chem., 2002, 1718-1728; (c) C. D. Antoniadis, G. Corban, S. K. Hadjikakou, N. Hadjiliadis, M. Kubicki, S. Warner and I. S. Butler, Eur. J. Inorg. Chem., 2003, 1635-1640; (d) C. D. Antoniadis, S. K. Hadjikakou, N. Hadjiliadis, M. Kubicki and I. S. Butler, Eur. J. Inorg. Chem., 2004, 4324-4329; (e) C. D. Antoniadis, S. K. Hadjikakou, N. Hadjiliadis, M. Kubicki and I. S. Butler, New J. Chem., 2005, 29, 714-720; $(f)$ G. J. Corban, S. K. Hadjikakou, N. Hadjiliadis, M. Kubicki, E. R. T. Tiekink, I. S. Butler, E. Drougas and A. M. Kosmas, Inorg. Chem., 2005, 44, 8617-8627; (g) C. D. Antoniadis, S. K. Hadjikakou, N. Hadjiliadis, A. Papakyriakou, M. Baril and I. S. Butler, Chem.-Eur. J., 2006, 12, 6888-6897; (h) S. K. Hadjikakou and N. Hadjiliadis, Bioinorganic Chemistry and Applications, 2006, 60291; (i) I.-E. Parigoridi, G. J. Corban, S. K. Hadjikakou, N. Hadjiliadis, N. Kourkoumelis, G. Kostakis, V. Psycharis, C. P. Raptopoulou and M. Kubicki, Dalton Trans., 2008, 5159-5165; (j) A. M. Owczarzak, M. Kubicki, N. Kourkoumelis and S. K. Hadjikakou, RSC Adv., 2012, 2, 2856-2867; (k) G. J. Corban, C. D. Antoniadis, S. K. Hadjikakou, N. Kourkoumelis, V. Yu. Tyurin, A. Dolgano, E. R. Milaeva, M. Kubicki, P. V. Bernhardt, E. R. T. Tiekink, S. Skoulika and N. Hadjiliadis, Heteroat. Chem., 2012, 23, 498-511; (l) J. H. Z. dos Santos, I. S. Butler, V. Daga, S. K. Hadjikakou and N. Hadjiliadis, Spectrochim. Acta, Part A, 2002, 58, 2725-2735.

3 P. D. Boyle, J. Christie, T. Dyer, S. M. Godfrey, I. R. Howson, C. McArthur, B. Omar, R. G. Pritchard and G. R. Williams, J. Chem. Soc., Dalton Trans., 2000, 3106-3112.

4 (a) F. Bigoli, P. Deplano, A. Ienco, C. Mealli, M. L. Mercuri, M. A. Pellinghelli, G. Pintus, G. Saba and E. F. Trogu, Inorg. Chem., 1999, 38, 4626-4636; (b) F. Bigoli, P. Deplano, M. L. Mercuri, M. A. Pellinghelli, A. Sabatini, E. F. Trogu and A. Vacca, J. Chem. Soc., Dalton Trans., 1996, 3583-3598; (c) D. Arzei, P. Deplano, E. F. Trogu, F. Bigou, M. A. Pellinghelli and A. Vacca, Can. J. Chem., 1988, 66, 1483-1489; (d) F. Cristiani, F. A. Devillanova, A. Diaz and G. Verani, J. Chem. Soc., Perkin Trans. 2, 1984, 1383-1386; (e) F. A. Devillanova and G. Verani, Tetrahedron, 1979, 35, 511-514; (f) M. C. Aragoni, M. Arca, F. Demartin, F. A. Devillanova, A. Garau, F. Isaia, V. Lippolis and G. Verani, J. Am. Chem. Soc., 2002, 124, 4538-4539; (g) P. Deplano, F. A. Devillanova, J. R. Ferraro, F. Isaia, V. Lippolis and M. L. Mercuri, Appl. Spectrosc., 1992, 46, 1625-1629; (h) M. C. Aragoni, M. Arca, M. B. Carrea, F. Demartin, F. A. Devillanova, A. Garau, F. Isaia, V. Lippolis and G. Verani, Eur. J. Inorg. Chem., 2004, 23, 4660-4668.

5 F. Freeman, J. W. Ziller, H. N. Po and M. C. Keindl, J. Am. Chem. Soc., 1988, 110, 2586-2591.

6 P. H. Svensson and L. Kloo, Chem. Rev., 2003, 103, 16491684.
7 W. W. du Mont, G. Mugesh, C. Wismach and P. G. Jones, Angew. Chem., Int. Ed., 2001, 40, 2486-2489.

8 W. T. Pennington, T. W. Hanks and H. D. Arman, Struct. Bonding, 2008, 126, 65-104.

9 C. Ouvrard, J.-Y. Le Questel, M. Berthelot and C. Laurence, Acta Crystallogr., Sect. B: Struct. Sci., 2003, 59, 512-526.

10 D. W. Allen, R. Berridge, N. Bricklebank, S. D. Forder, F. Palacio, S. J. Coles, M. B. Hursthouse and P. J. Skabara, Inorg. Chem., 2003, 42, 3975-3977.

11 (a) Q. Li, R. Li, Z. Zhou, W. Li and J. Cheng, J. Chem. Phys., 2012, 136, 14302; (b) P. J. Skabara, Annu. Rep. Prog. Chem., Sect. A, 2002, 98, 93-105.

12 L. C. King and I. Ryden, J. Am. Chem. Soc., 1947, 69, 18131814.

13 M. A. Metwally, E. Abdel-Latif, F. A. Amer and G. Kaupp, J. Sulfur Chem., 2004, 25, 63-85.

14 (a) A. Kleemann and J. Engel, Pharmaceutical Substances, 4th edn, 2001; (b) B. A. Baviskar, S. S. Khadabadi and S. L. Deore, J. Chem., 2013, 656271; (c) S. M. Basavarajaiah and B. H. M. Mruthyunjayaswamy, Indian J. Chem., 2010, 49B, 1117-1126; (d) N. J. Thumar and M. P. Patel, Arch. Pharm. Chem. Life Sci., 2011, 2, 91-101; (e) G. N. Sasidharan, K. Mohanan and A. N. LakshimPrabha, Asian J. Chem., 2002, 14, 1545-1550; (f) A. B. Nadkarni, R. V. Kamath and G. B. Khadse, Indian J. Heterocycl. Chem., 2000, 9, 309; (g) K. A. Karpov, B. V. Pekarevskii and V. M. Potekhin, Russ. J. Gen. Chem., 2001, 79, 1484-1486; (h) M. Lang, M. H.-J. Seifert, K. K. Wolf, A. Aschenbrenner, R. Baumgartner, T. Wieber, V. Trentinaglia, M. Blisse, N. Tajima, T. Yamashita, D. Vitt and H. Noda, Bioorg. Med. Chem. Lett., 2011, 21, 54175422.

15 (a) F. M. Awadallah, Sci. Pharm., 2008, 76, 415-438; (b) S. Ueda, H. Terauchi, M. Kawasaki, A. Yano and M. Ido, Chem. Pharm. Bull., 2004, 52, 634-637; (c) D. G. Craciunescu, A. Furlani, V. Scarcia and A. Doadrio, Biol. Trace Elem. Res., 1985, 8, 251-261; (d) V. A. Morde, M. S. Shaikh, R. R. S. Pissurlenkar and E. C. Coutinho, Mol. Divers., 2009, 13, 501-517; (e) S. R. Pattan, V. V. K. Reddy, P. D. Pawar, N. S. Desai, A. R. Bhat and A. D. Taranalli, Orig. Res. Articles, 2006, 8, 253; $(f)$ M. Ohkubo, A. Kuno, I. Nakanishi and H. Takasugi, Chem. Pharm. Bull., 1995, 43, 1497; (g) S. R. Pattan, V. V. K. Reddy, F. V. Manvi, B. G. Desai and A. R. Bhat, Indian J. Chem., 2006, 45B, 1778-1781; (h) G. M. Dubowchik, J. A. Michne, D. Zuev, W. Schwartz, P. M. Scola, C. A. James, E. H. Ruediger, S. S. Pin, K. D. Burris, L. A. Balanda, Q. Gao, D. Wu, L. Fung, T. Fiedler, K. E. Browman, M. T. Taber and J. Zhang, Bioorg. Med. Chem. Lett., 2003, 13, 3997-4000.

16 (a) V. S. Ashalekshmi and K. Mohnan, Asian J. Chem., 2008, 20, 623-628; (b) Y. Sindhu, C. J. Athira, M. S. Sujamol and K. Mohnan, Phosphorus, Sulfur Silicon Relat. Elem., 2010, 185, 1955-1963; (c) M. Bröring and C. Kleeberg, Inorg. Chim. Acta, 2007, 360, 3281-3286.

17 (a) K. Singh, S. Singh and J. A. Taylor, Dyes Pigm., 2002, 54, 189-200; (b) M. She, Z. Yang, B. Yin, J. Zhang, J. Gu, 
W. Yin, J. Li, G. Zhao and Z. Shi, Dyes Pigm., 2012, 92, 1337-1343; (c) X.-L. He, Y.-Q. Wang and K.-Q. Ling, Talanta, 2007, 72, 747-754; (d) K. A. Karpov, A. V. Nazarenko, B. V. Pekarvskii and V. M. Potekhin, Russ. J. Appl. Chem., 2001, 74, 998-1001; (e) L. N. Rasina and O. N. Chupakhin, Radioekologiya, 1999, 39, 223-226.

18 (a) A. Castro, T. Castaño, A. Encinas, W. Porcal and C. Gil, Bioorg. Med. Chem. Lett., 2006, 14, 1644-1652; (b) L. Florani and C. Boga, J. Chem. Soc., Perkin Trans. 2, 2002, 768-772.

19 (a) Y. Kohara, K. Kubo, E. Imamiya, T. Wada, Y. Inada and T. Naka, J. Med. Chem., 1996, 39, 5228-5235; (b) U. K. M. Decking, M. Hartmann and J. Schrader, Naunyn-Schmiedeberg's Arch. Pharm., 1998, 358, 547-553; (c) M. Hartmann, U. K. M. Decking and J. Schrader, Naunyn-Schmiedeberg's Arch. Pharm., 1998, 358, 554-560; (d) A. Lanzafame and A. Christopoulos, J. Pharmacol. Exp. Ther., 2004, 308, 830-837; (e) T. F. Tam, R. Leung-Toung, W. Li, M. Spino and K. Karimian, Mini Rev. Med. Chem., 2005, 5, 367; (f) J. Marcinkieviciene, M. J. Rogers, L. Kopcho, W. Jiang, K. Wang, D. J. Murphy, J. Lippy, S. Link, T. D. Y. Chung, F. Hobbs, T. Haque, G. L. Trainor, A. Slee, A. M. Stern and R. Copeland, Biochem. Pharmacol., 2000, 60, 339-342; (g) Y. Song, D. T. Connor, A. D. Sercel, R. J. Sorenson, R. Doubleday, P. C. Unangst, B. D. Roth, V. G. Beylin, R. B. Gilbersten, K. Chan, D. J. Schrier, A. Guglietta and D. A. Bornemeier, J. Med. Chem., 1999, 42, 1161-1169; (h) Y. Iizawa, K. Okonogi, R. Hayashi, T. Iwahi, T. Yamazaki and A. Imada, Antimicrob. Agents Chemother., 1993, 37, 100-105; (i) A. Martinez, M. Alonso, A. Castro, C. Pèrez and F. J. Moreno, J. Med. Chem., 2002, 45, 12921299.

20 (a) T. B. Johnson and C. O. Edens, J. Am. Chem. Soc., 1942, 64, 2706-2708; (b) F. H. Herbstein and W. Schwotzert, J. Am. Chem. Soc., 1984, 106, 2367-2373.
21 C. Laurence, M. J. El Ghomari, J-Y. Le Questel, M. Berthelot and R. Mokhlisse, J. Chem. Soc., Perkin Trans. 2, 1998, 1545-1551.

22 (a) O. Foss, J. Johnsen and O. Tvedten, Acta Chem. Scand., 1958, 12, 1782-1798; (b) T. Lis and P. Starynowicz, Acta Crystallogr., Sect. C: Cryst. Struct. Commun., 1985, 41, 12991302.

23 (a) D. Jiao, M. Barfield, J. E. Combariza and V. J. Hruby, J. Am. Chem. Soc., 1992, 114, 3639-3643; (b) W.-K. Li, S.-W. Chiu, Z.-X. Ma, C.-L. Liao and C.-Y. Ng, J. Chem. Phys., 1993, 19, 8440-8444; (c) M. F. Erben and C. O. Della Védova, Helv. Chim. Acta, 2003, 86, 2379-2395.

24 N. R. Kuncher and M. R. Truter, J. Chem. Soc., 1958, 25512557.

25 (a) M. Hołyńska, M. Korabik and M. Kubiak, Polyhedron, 2010, 29, 530-538; (b) M. Hołyńska and M. Kubiak, Acta Crystallogr., Sect. C: Cryst. Struct. Commun., 2008, 64, 06090612.

26 J. Coetzee, S. Cronje, L. Dobrzańska, H. G. Raubenheimer, G. Jooné, M. J. Nellb and H. C. Hoppe, Dalton Trans., 2011, 40, 1471-1483.

27 (a) S. J. Rettig and J. Trotter, Acta Crystallogr., Sect. C: Cryst. Struct. Commun., 1987, 43, 2260; (b) A. C. Gallacher and A. A. Pinkerton, Acta Crystallogr., Sect. C: Cryst. Struct. Commun., 1993, 49, 125; (c) M. Bolte, Private Communication, 2005; (d) L. M. Goldsmith and C. E. Strouse, J. Am. Chem. Soc., 1977, 99, 7580.

28 (a) A. Altomare, G. Cascarano, C. Giacovazzo and A. Gualardi, J. Appl. Crystallogr., 1993, 26, 343-350; (b) C. K. Johnson, ORTEPII. Report ORNL-5138, Oak Ridge National Laboratory, Tennessee, USA, 1976; (c) C. F. Macrae, I. J. Bruno, J. A. Chisholm, P. R. Edgington, P. McCabe, E. Pidcock, L. RodriguezMonge, R. Taylor, J. van de Streek and P. A. Wood, J. Appl. Crystallogr., 2008, 41, 466-470. 